\title{
PODER E LIDERANÇA DAS MULHERES NAS CARREIRAS POLÍTICAS, DO JUDICIÁRIO, MINISTÉRIO PÚBLICO E NA ADVOCACIA PRIVADA*
}

\author{
Elisandra de Oliveira Justo** \\ Maria Claudia Felten***
}

\section{RESUMO}

A importância da liderança feminina nas organizações está sendo discutida com maior frequência e por novas perspectivas dentro da academia levando as instituições a investirem em pesquisas e treinamentos para igualdade de gênero. A presença cada vez mais significativa da mulher no mercado de trabalho, e em especial nas instituições públicas e na advocacia, tem deixado mais evidente a sub-representação feminina nos cargos de liderança e em posições de tomada de decisões. A partir dessas informações, o presente artigo tem como objetivo analisar e discutir os principais aspectos da participação das mulheres na sociedade, e como elas são vistas pelos homens e pelas próprias mulheres. Num primeiro momento se buscou diversas autoras de várias épocas, áreas e especialidades para definirem o que é ser mulher e quais os preconceitos e dificuldades que enfrentam na busca por igualdade de gênero. Logo após se procurou avaliar o quanto as lideranças femininas influenciam na definição dos papeis de gênero e se esta pré concepção do que é ser mulher interfere na ascensão da carreira profissional feminina. Por meio

* Artigo apresentando ao Curso de Direito do Centro Universitário Metodista - IPA, na área de concentração do Direito do Trabalho como requisito parcial para obtenção do grau de Bacharela em Direito.

** Graduanda do Curso de Bacharelado em Direito do Centro Universitário Metodista - IPA.

*** Orientadora do artigo, Doutora em Direito e professora do Curso de Bacharelado em Direito do Centro Universitário Metodista - IPA. 
de pesquisa bibliográfica, isto é, o estudo com base em material publicado em livros, revistas, jornais, redes eletrônicas, e conversas com palestrantes e estudiosas sobre o tema foi possível uma compreensão dos desafios para conciliar a vida profissional com a vida pessoal. 0 escopo do ensaio é, portanto, propor reflexões acerca da divisão sexual do trabalho e o acumulo de funções, quais as ações afirmativas que estão sendo implantadas para garantir igualdade gênero e as vantagens da diversidade no ambiente de trabalho. Para isto foram avaliadas mulheres das carreiras políticas, do judiciário, ministério público e na advocacia privada que conseguiram assumir o topo de suas carreiras quebrando o chamado "teto de vidro".

Palavras-Chave: liderança feminina; igualdade de gênero; mulher;

\section{POUVOIR ET LEADERSHIP DES FEMMES DANS LES CARRIÈRES POLITIQUES, LA MAGISTRATURE, LE MINIS- TÈRE PUBLIC ET LE PLAIDOYER PRIVÉ}

\section{RÉSUMÉ}

L'importance du leadership des femmes dans les organisations fait l'objet de discussions plus fréquentes et de nouvelles perspectives au sein du monde universitaire, les principales institutions investissant dans la recherche et la formation pour l'égalité des sexes. La présence de plus en plus importante de femmes sur le marché du travail, et en particulier dans les institutions publiques et le plaidoyer, a accentué la sous-représentation des femmes aux postes de direction et de prise de décision. À partir de cette information, cet article vise à analyser et à discuter les principaux aspects de la participation des femmes à la société et de la façon dont ils sont vus par les hommes et les femmes. Au début, plusieurs auteurs de différentes époques, régions et spécialités ont été recherchés pour définir ce qu'est une femme et quels sont les préjugés et les difficultés auxquels elle est confrontée dans la recherche de l'égalité des sexes. Peu de temps après, on a essayé d'évaluer dans quelle mesure les femmes dirigeantes influaient sur la définition des rôles de genre et si cette idée préconçue de ce que c'est que d'être une femme interfère dans l'ascension de leur carrière professionnelle. Par le biais de la recherche bibliographique, il s'agit d'une, étude basée sur des documents publiés dans des livres, des revues, des journaux, des réseaux électroniques et des conversations avec des conférenciers et des universitaires sur le sujet ont permis de comprendre les défis à relever pour concilier vie professionnelle et vie privée. . L'objectif de l'essai est donc de proposer des réflexions sur la division sexuelle du travail et l'accumulation de fonctions, sur les actions 
affirmatives mises en œuvre pour garantir l'égalité des sexes et sur les avantages de la diversité dans l'environnement de travail. À cette fin, des femmes de carrières politiques, de l'appareil judiciaire, du parquet et de juristes du secteur privé ont été évaluées et ont été en mesure de prendre le meilleur de leur carrière en brisant le prétendu "plafond de verre".

Mots-clés: leadership féminin; égalité des sexes; les femmes;

\section{INTRODUÇÃO}

A mulher vem se destacando cada vez mais, mostrando que está preparada para o mercado de trabalho, quebrando as barreiras e preconceito que vem enfrentando ao longo da historia. A mulher está mudando, conquistando seu lugar e apostando nos valores femininos. Elas estão conseguindo seu espaço no mercado de trabalho e atingindo postos de lideranças nas organizações que antes eram conquistados unicamente por homens, entretanto para chegar ao topo, as mulheres passam por discriminações e sofrem com as desigualdades salariais existentes entre homens e mulheres. Elas buscam superar esses entraves com garra e espírito competitivo e, ao conquistar o mercado de trabalho, adquirem sua independência financeira, tornam-se participativas econômica e socialmente, o que as levam a desenvolver, ainda mais, a autoestima e a auto realização, provando que são capazes de liderar e administrar conflitos, com perfil diferenciado, com versatilidade e persuasão, quebrando paradigmas. A evolução da presença feminina no mercado de trabalho, e o papel da mulher na liderança de grandes organizações brasileiras, são marcados pelas mudanças do entendimento do que se espera de um líder juntamente com transformação da percepção das características femininas. Esta nova roupagem dos cargos de liderança permitiu a valorização do estilo e habilidades de comando das mulheres nos órgãos públicos e nas empresas privadas. Em uma analise das carreiras políticas, do judiciário, ministério público e na advocacia privada se pode balizar as conquistas e barreiras para a equidade e transversalidade de gênero das mulheres que atuam nos diversos seguimentos da justiça. 


\section{ESTUDANDO AS MULHERES}

Nesta seção será analisada como renomadas escritoras conceituam o que é ser mulher. Como é feita a construção de gênero e o que define o ser como homem ou mulher. E também avaliará a desigualdade histórica sofrida pelas mulheres, bem como abordará os desejos e as angústias femininas ao longo da história.

\subsection{A EVOLUÇÃO REVOLUÇÃO DAS MULHERES}

0 que é ser mulher?

Elizabete Silva, professora e mestre do Estado da Bahia, em sua pesquisa concluiu que "ser mulher não é uma condição natural, mas uma construção social e cultural em constante reelaboração na dinâmica da sociedade" (2006, p.37). Conclusão semelhante construída pela professora Alessandra Gonzaga ${ }^{1} \mathrm{em}$ sua palestra sobre liderança feminina na Unisinos ${ }^{2}$. As pesquisadoras referidas destacaram que para se definir o que é ser mulher não se pode ter parâmetros morais e comportamentais de uma determinada sociedade, de uma determinada época e generalizar como sendo o correto para todas as sociedades de todo o planeta em todas as épocas. "A mulher deve ser concebida e reconhecida no conjunto das condições econômicas, sociais e culturais em que está inserida" (2006, p.37). As mulheres precisam ser compreendidas pelas macro e micro estruturas da sociedade em que vivem.

Simone de Beauvoir, no primeiro volume de sua obra o segundo sexo, tenta desvendar quem é a mulher e se existe a essência feminina. Nela a autora analisa a biologia, o ponto de vista psicanalítico e o materialista. A escritora não nega que existe uma natureza feminina, mas alega que a biologia não basta para justificar a subordinação da mulher na sociedade. (1967, p. 25-27).

1 Professora e Coach de inteligência emocional. Doutoranda em gestão de pessoas, mestre em psicologia clínica. Sócia-diretora da conexão IE.

2 Curso de extensão: liderança feminina: desafios e oportunidades, organizado por conexão IE. Ocorrido em 2 de out - 4 de out 2018. Campus Unisinos Porto Alegre. 
A filósofa não acredita que possa existir um complexo de inferioridade feminina, como alegava Freud, mas sim que a sociedade, com seu contexto, induz a mulher a determinado comportamento. Diz ainda que as questões de gênero superam as questões econômica. Há uma educação para que a matéria prima fêmea vire o produto mulher, e se é uma questão de educação as mulheres podem ser diferentes do que estamos acostumados a ver como "mulher" (BEAUVOIR, 1967, p. 9).

\begin{abstract}
Ninguém nasce mulher: Torna-se mulher. Nenhum destino biológico, psíquico, econômico define a forma que a fêmea humana assume no seio da sociedade: é o conjunto da civilização que elabora esse produto intermediário entre o macho e o castrado que qualificam de feminino. (BEAUVOIR,1967, p. 9).
\end{abstract}

Beauvoir ainda nos lembra que de uma forma quase que generalizada (em todas as épocas e sociedades) a construção social que se fez para a mulher foi de submissão e inferioridade perante o homem. Desta forma, para transcender será necessária uma transformação mais profunda, não apenas individual. Porque não basta conquistar o direito ao trabalho e o direito à cultura. Para a escritora o trabalho das mulheres é exploração, e ela justifica sua afirmação com os argumentos de que é um trabalho menos remunerado que o do homem (dados históricos e atuais) e também porque as mulheres acabam com, no mínimo, uma dupla jornada, uma vez que não deixam de fazer os trabalhos domésticos e a tarefa de educar e cuidar dos filhos. (1967, p. 73-77).

Esta importante pensadora francesa do sec. XX critica fortemente Aristóteles, uma vez que discorda que a mulher seja um homem incompleto, ou que a definição de mulher seja um "ser não-homem", ou mesmo ainda que a mulher seja o ser negativo da espécie, e o homem o ser positivo e neutro (por isto se utiliza "homem" para se referir a todos da espécie humana). Assim Aris- 
tóteles definia que o homem era o sujeito e a mulher o objeto na espécie, o que justificaria a inferioridade da mulher. Claro que de um ponto de vista masculino, com justificativas feitas por uma perspectiva masculina, do ser que escreveu a história da humanidade. (1967, p. 30-35).

Christine de Pizan $^{3}$ refutava a literatura masculina misógina, e escrevia em prol da igualdade entre os sexos, defendia assim, como outras escritoras, referenciadas nessa pesquisa, que as diferenças eram construções sociais e não caracteres inatos. Seu trabalho foi voltado à desconstrução dos modelos preconceituosos sobre a mulher e de reconstrução da imagem feminina perante os homens e até mesmo perante as próprias mulheres. (2012, p. 115-120)

[...] procurando à minha volta algum livrete, caiu entre minhas mãos um certo opúsculo que não me pertencia, mas que alguém havia deixado ali, com outros volumes, por empréstimo. Abri-o, então, e observei no título que se tratava de Mateolo137. Pus-me, então, a rir, pois não o havia lido antes, mas sabia que, entre outros livros, esse tinha a reputação de falar bem das mulheres! Pensei, então, que para me divertir um pouco, poderia percorrê-lo. [...] Pus-me a lê-lo. Avancei um pouco a leitura. Mas, o assunto parecendo-me tão pouco agradável -, aliás, para qualquer um que não se deleita com calúnias -, e sem contribuir em nada à edificação moral nem à virtude, considerando ainda a desonestidade da linguagem e dos temas por ele tratados, folheei-o aqui, ali, li o final, e, em seguida, abandonei-o para voltar a outros estudos mais sérios e de maior utilidade. Porém, a leitura daquele livro, apesar de não ter nenhuma autoridade, suscitou em mim uma reflexão que me atordoou profundamente. Perguntava-me quais poderiam ser

3 Christine de Pizan, poetisa e filósofa italiana que viveu na França durante primeira metade do século XV. Crítica literária da época defendia o papel vital das mulheres na sociedade. 
as causas e motivos que levavam tantos homens, clérigos e outros, a maldizerem as mulheres e a condenarem suas condutas em palavras, tratados e escritos. Isso não é questão de um ou dois homens, nem mesmo só deste Mateolo, a quem não situaria entre os sábios, pois seu livro não passa de gozação; pelo contrário, nenhum texto está totalmente isento disso. Filósofos, poetas e moralistas, e a lista poderia ser bem longa, todos parecem falar com a mesma voz para chegar à conclusão de que a mulher é profundamente má e inclinada ao vício. (Pizan, 2012, p.118-9)

A psicanalista e poetisa, Maria Rita $\mathrm{Kehl}^{4}$ também tese sobre a perspectiva de que anatomia não é destino, que a vida da mulher e o que é ser mulher, não está marcada no nascimento. Com isto, a escritora nos remete para literatura de Madame Bovary ${ }^{5}$, que discute a oportunidade que todas temos durante a vida de tornarmos "outros", fugindo do estereótipo das condições de nascimento e desconstruindo a figura abstrata de A Mulher, este conjunto de imagens e representações que tentam produzir uma identidade para todas as mulheres (1998, p.312- 313).

[...] toda mulher em transição para a modernidade seria uma bovarista, empenhada pela via imaginária em "tornar-se uma outra" e, ao mesmo tempo, capturada por uma posição na trama simbólica de completa dependência em relação ao que o homem poderia desejar dela. A demanda fálica dirigida aos homens (sempre insatisfeita), as formas sintomáticas de denúncia da impotência masculina em

4 Maria Rita Kehl é psicanalista, doutora em psicanálise pela PUC de São Paulo, jornalista e escritora. Em 2010, venceu o Prêmio Jabuti de Literatura na categoria "Educação, Psicologia e Psicanálise".

5 Madame Bovary é a obra que inaugura o estilo literário Realismo. 0 livro conta a história de uma jovem romântica e sonhadora, Emma, que, frustrada com seu casamento e inspirada pelos romances que lê vorazmente, inicia uma jornada de casos amorosos que a levam à ruína. 
fazer dela uma mulher, as tentativas de manobrar o desejo do qual se fez objeto e o fracasso subjetivo dessa empreitada, fizeram da histérica a figura mais representativa da relação entre a mulher e a feminilidade, do final do século passado [século XIX] até pelo menos a primeira metade deste [século XX] (KEHL, 1998, p.313).

Neste contexto, no subtítulo, os homens constroem a feminilidade, Kehl propõe o conceito de deslocamento para acompanhar as mudanças nos conceitos de feminino e de feminilidade, pois estas definições são determinadas pelas condições históricas da cultura, pelo conjunto das representações singulares que as mulheres passam a ter sobre si mesmas e bem como suas participações como fundadoras destes conceitos, na medida que lutam para construir contrapontos com vozes femininas na literatura e em autobiografias, refutando a dita "natureza feminina". No imaginário burguês, a mulher era sinônimo de ser sensível e amorosa, destinada ao casamento e a maternidade, funções estas que só realizava quando domesticada (passava daquilo que ela era para aquilo que ela deveria ser ${ }^{6}$.

A cientista política Flávia Biroli diz que a produção do gênero se dá nas relações de trabalho, e a divisão sexual do trabalho desencadeia a produção do gênero, uma vez que o sentido do masculino e do feminino está ligado com as expectativas e responsabilidades que devem ser desempenhadas, levando a construção do que é se tornar uma mulher. "A divisão sexual do trabalho é um lócus importante da produção do gênero". (2018, p.21-23)

\subsection{MULHER DE ONTEM E DE HOJE}

A mulher deste século quer igualdade, como explica em seu livro Chin-Ning Chu, este é um fenômeno internacional, que

6 Palestra "Deslocamentos do Feminino - A mulher freudiana na passagem para a modernidade" no Instituto Vox no dia 2008 14. https://www. youtube.com/watch?v=o1yDVuY77Bc 
está em uma corrente de feminilidade universal que ultrapassa culturas e fronteiras. Se antes as mulheres sonhavam e se preparavam para se casar com um milionário, hoje querem e estão se preparando para serem milionárias $(2014$, p.4)

Nas charges de Maitena, autora nascida em Buenos Aires na década de 60, se visualiza as relações de gênero social e mostram as mudanças nas aspirações femininas no passar do tempo. $\mathrm{Na}$ série mulheres alteradas, suas tirinhas buscavam tentar revelar a alma feminina, resumindo os conflitos pelos quais as mulheres passaram e continuam passando nas sociedades ocidentais, com isto ela caracterizava o que havia de mais comum nos ideais das jovens de cada época. (2003)

Ao responder à questão "o que você quer ser quando crescer?", as jovens responderiam:

1940: mãe

1950: professora

1960: astronauta

1970: presidente

1980: milionária

1990: solteira (MAITENA, 2003, v. 1, p. 75):

Conforme Maitena, os movimentos feministas trouxeram a possibilidade de as mulheres externarem sua revolta contra a submissão em relação aos homens. As figuras femininas retratadas nesses quadrinhos estão quase sempre "insatisfeitas", uma vez que o mundo está em constante transição e as mulheres tentam entender qual é o seu papel na sociedade, isto as coloca em conflito, gerando assim pensamentos contraditórios.

As estratégias femininas para a conquista da satisfação pessoal, segundo a cartunista, nada mais são do que o esforço para a inserção social na vida moderna. A autora ainda lembra que as mulheres foram alvo de acusações e julgamentos, sendo objeto de estudos para os homens. (MAITENA, 2003, v. 4, p. 93) 
1920: de frívolas (Quero ir a Paris dançar Fox-trot!) 1930: de sentimentais (Quero um marido romântico... e filhinhos carinhosos!)

1940: de frágeis (... Não quero saber... e quero uma aspirina, por favor!)

1950: de consumistas (Quero uma máquina de lavar! E um liquidificador! E um toca-discos! E um carro!)

1960: de histéricas (Quero ser livre! Livre!!)

1970: de incompreendidas (Quero me sentir realizada... Entende...?)

1980: de insatisfeitas (... Não sei o que quero...)

1990: de alteradas (Quero parar...! Mas não posso...!)

(MAITENA, 2003, v. 4, p. 93)

Charlotte Perkins Gilman, em seu livro Herland, a Terra das Mulheres publicado em 1915 descreve uma sociedade utópica formada unicamente por mulheres, história que foi a inspiração para a criação da super heroína, mulher maravilha. Sua obra é considerada poderosa e revolucionaria por seus questionamentos. “Elas não parecem perceber que somos homens", ele disse. "Elas nos tratam... bem... como tratam umas às outras. É como se o fato de sermos homens fosse apenas um detalhe menor". (2018, p. 62)

As mulheres desta terra dedicam a vida à criação colaborativa de filhas e ao desenvolvimento da ciência para melhoria da vida de toda a sociedade, elas jamais abrem mão de sua independência e do controle sobre o próprio corpo e emoções. Gilman não perde tempo com nada que não seja sua reflexão sobre os papéis de gênero. Conduzindo os leitores pela compreensão que toda a devoção, renúncia, lealdade e trabalho que as mulheres dedicam nos seus espaços privados, as mulheres desta terra ofereciam em prol das coletivamente. (2018, p.111-126)

Os questionamentos provocados pela obra continuam pertinentes até hoje. As mulheres vão ao longo da história mudando o entendimento sobre autonomia, estereótipos femininos e sororidade. (2018, p. 163-164) 
Ela olhou para os campos, onde algumas mulheres trabalhavam, erguendo um muro de pedras grandes; voltou o olhar para a cidade mais próxima, com casas construídas por mulheres; desceu o olhar para a estrada reta e dura sobre a qual caminhavam; e depois para a cestinha que ele havia tirado dela... as mulheres no seu país são tão fracas que não conseguem carregar uma coisinha dessa? (Gilman, 2018, p. 163-164)

A jornalista e consultora de comportamento feminino, Joyce Moysés nos traz como exemplo o conto de fadas da Disney Rapunzel, que antes era uma indefesa princesa esperando o príncipe encantado, agora a princesa se apaixona por um bandido e o chantageia para conseguir a própria liberdade. (2011, p. 28)

Para a escritora existe grande movimento nas redes sociais e nos variados meios de comunicação demonstrando a força das mulheres, viabilizando assim a quebra dos estereótipos tidos como femininos. Um dos exemplos citados pela escritora é a ideia de que as mulheres são competitivas e invejosas entre si (guerra do batom). (2011, p. 29)

Charlotte já tinha o mesmo posicionamento de Joyce quanto a esta suposta rivalidade entre as mulheres. Para ela é mais um dos comportamentos tidos como feminino dentro de uma sociedade machista e patriarcal, pois é passado para as mulheres, desde a infância, que ela são concorrentes, que devem disputar para ver quem fica com o melhor homem, e para isto, elas devem competir para ver quem o agrada mais. Charlotte em sua terra das mulheres tenta demonstrar que as mulheres não se vêem como rivais, mas sim como irmãs, que entendem as necessidades umas das outras e que se ajudam. E também que as mulheres não são seres indefesos, ou inferiores fisicamente e mentalmente, pelo contrário, as mulheres são guerreiras, trabalham muito bem em equipes, são criativas e possuem uma maior capacidade de percepção e sensibilidade ao contexto. (2018, p. 26-27 e 117-121) 
Soraia Schutel ${ }^{7}$, em sua palestra ${ }^{8}$ na $\mathrm{WLM}^{9}$ concorda com Joyce Moysés e com Charlotte que as mulheres praticam a sororidade, que buscam por parceiras de vida e que crescem juntas. As mulheres se auxiliam principalmente no lado não cognitivo, na autoestima que é tão importante para que as mulheres se valorizem e produzam no máximo de seu potencial. Diz que as mulheres criam verdadeiras redes de apoio. Exemplifica a força das mulheres com a sugestão de leitura da biografia de Catarina a Grande, a última mulher que governou a Rússia, de 1762 a 1796. A dura vida de uma mulher que pertence ao Estado, que transformou a Rússia, e reformou o código de leis trazendo princípios humanistas às relações de trabalho, às leis penais e civis, e ao mesmo tempo manteve seus mais profundos valores.

Christine de Pizan, que foi uma das figuras femininas de maior destaque na idade média, em sua obra a cidade das mulheres, escrita em 1804, já conseguiu reunir estimado número de mulheres que foram indispensáveis à evolução da sociedade, com isto destacando o quanto é longa à questão feminina face à diferença de gênero, e o quanto a coletividade pode se beneficiar com a diversidade. (2012)

Pizan, foi uma mulher visionaria, tinha a preocupação com

7 Co-fundadora e CEO da Sonata Brasil, escola de educação de lideranças. Doutora em Administração pela Universidade Federal do Rio Grande do Sul. Pesquisadora na área de Aprendizagem Transformadora, Inovação na educação de líderes e Desenvolvimento Sustentável. Especialista em Psicologia Social pela Universidade estatal de São Petersburgo-Rússia. Apresentadora do quadro "Soraia, me dá uma luz" com orientação de carreira para mulheres no programa Super poderosas da Band. Professora da Escola de Você, maior plataforma educacional de empoderamento feminino da América Latina com mais de 500 mil alunas.

8 Evento do WLM, eventos de desenvolvimento de carreira e liderança - Trilha de Palestras promovida pelo WLM, palestra Estratégias para a Liderança Feminina. Ocorrida em 22.10.2018, na casa da confraria, em Poa \RS

9 women in law mentoring brazil - WLM-BR é uma associação sem fins lucrativos, cujo objetivo é proporcionar o desenvolvimento de advogadas, estimulando a criação de futuras lideranças femininas tanto em escritórios de advocacia como em jurídicos de empresa. 
a divulgação e durabilidade das suas obras, já prevendo que as questões como a igualdade entre os sexos, a violência física contra a mulher, e outras lutas continuariam sendo motivo de protestos e discussões por um longo tempo. (2012)

No filme "eu não sou um homem fácil", comédia romântica francesa de 2018, dirigida por Éléonore Pourriat, mostra em um contexto de feminismo, um homem passando o que vivem diariamente as mulheres: pressões estéticas, assédios, subestimações, relacionamentos abusivos e até "sororidade invertida". Expondo que a educação poderia criar uma mulher diferente. A existência feminina foi construída, e a existência pode mudar.

\subsection{IGUALDADE DE GÊNERO E PRECONCEITOS}

Para Amartya Sen igualdade está relacionada com o que as pessoas são capazes de realizar e na remoção de obstáculos que impeçam o desfrute de uma vida que elas entendam valiosa. As peculiares individuais importam "liberdades substantivas", o bem-estar dos indivíduos, em uma dimensão ampla do bem-estar humano e o desenvolvimento social para a realização de projetos de vida. (2008)

Beauvoir ao fazer uma retrospectiva histórica observa que será necessária uma luta árdua para mudar a sociedade como um todo e principalmente, na esfera do trabalho. (1967, p.164 - 167).

Os países latinos, como os países orientais, oprimem a mulher pelo rigor dos costumes mais do que pelo rigor das leis. Na Itália, o fascismo freou sistematicamente a evolução do feminismo. Procurando a aliança da Igreja, respeitando a família e prolongando uma tradição de escravidão feminina, a Itália fascista escravizou duplamente a mulher: aos poderes públicos e ao marido (BEAUVOIR, 1967, p.164). 
Existe a desigualdade biológica entre homens e mulheres? Kehl em uma palestra ${ }^{10}$ sobre sua tese de doutoramento, deslocamentos do feminino - a mulher freudiana na passagem para a modernidade, faz uma análise referencial psicanalítica de Freud e Lacan, assim como traz vária obras já conceituadas da sociologia contemporânea, por exemplo: Flaubert, Dostoievski, Peter Gay, Richard Sennett, Michel Foucault, dentre outros, onde a psicanálise teorizou as "patologias femininas", muitas, até hoje, tidas como verdades.

Kehl na mesma palestra ainda diz ter concluído que Freud limitou a sua visão da feminilidade como uma falta de capacidade sublimatória e não como falta de liberdade de ação. Enquanto que para Lacan a escritora acredita que ele trabalhava com a ideia da inveja do falo, e não do pênis, pois as mulheres modernas estudadas na época estavam em crise com os papéis sociais impostos por uma sociedade em transformação, elas ansiavam por espaços, até então, restritos aos homens.

A escritora também faz referência que a visão de diferença biológica de gênero é baseada em teorias sexuais infantis, pois as mulheres são marcadas como "as castradas", as que não tinham nada a perder, no corpo. A cultura patriarcada temia esta mulher e tentava conter a desmesura da mulher. Esta construção foi feita porque o simbólico sem o elemento imaginário se fragiliza, e este poder só é potência se for chancelado pelo desejo do outro, criando a ideia de Anatomia-destino. E o homem, o ser que tinha tudo (pênis, poder, domínio sobre tudo e sobre todos) cria assim, restrições no casamento e na sociedade para as mulheres.

A fundadora da Casa da Mãe Joanna ${ }^{11}$, CDMJ, Joanna Burigo ${ }^{12}$ palestrou no sindicato dos trabalhadores do judiciário

10 https://www.youtube.com/watch?v=o1yDVuY77Bc

11 A Casa da Mãe Joanna é um espaço aberto de mídia; o conteúdo é produzido pelas autoras, e de responsabilidade e propriedade delas.http://casadamaejoanna.com/

12 Joanna Burigo é mestre em Gênero, Mídia e Cultura pela London SchoolofEconomicsandPolitical Science. 
federal no rio grande do sul, SINTRAJUFE, no I seminário ${ }^{13}$ de mulheres deste sindicato, e trouxe para discussão o apagamento sistemático das intervenções das mulheres ao longo da história. Esquematizou uma linha do tempo contando sobre as histórias de mulheres notáveis, mas ignoradas pelos livros de história. Um silenciamento difícil de romper que gera resistências para mostrar que a humanidade não é composta somente por homens. Lembra que fala-se desde a Grécia Antiga "das mulheres, é melhor que delas nada se fale. Daí você não fala, não escreve, não deixa que elas escrevam, daí, diante dos vazios, diz que elas não fizeram nada, nem são capazes".

Jacky Fleming vencedora do prêmio Artemísia em 2017, na categoria humor, prêmio este que foi criado em 2008 por quadrinistas francesas para premiar mulheres, devido ao preconceito contra as obras femininas. Fleming fala que as mulheres estão se esforçando para tirar suas antepassadas do "lixo da História" (2018, contracapa)

A cartunista em sua obra, qual o problema das mulheres, ironiza e debocha das limitações impostas às mulheres, nos conduzindo por "grandes pensadores" masculinos e expondo suas falas vergonhosas e misóginas, pessoas como Charles Darwin, Picasso, Rousseau, Schopenhauer, Charcot, Freud, Barão de Coubertin, Ruskin, etc. Este livro é uma sátira bem ácida sobre os estereótipos de mulher e sobre a ausência da presença feminina no decorrer da história. (Fleming, 2017, capa)

O intelecto feminino não serve para inventar ou criar... Sua maior função é elogiar; (...) Algumas mulheres histéricas queriam até se tornar médicas, quando o que precisavam era de um tratamento para a inveja do pênis - mas Freud, o gênio, ainda não o tinha inventado;(...) Gênios

13 Ocorrido em 28 e 29 de outubro 2018. https://www.sintrajufe.org.br/files/ nossas_publicacoes/403.pdf 
como o primo de Darwin eram fascinados pelo fato de todos os gênios serem homens.(Fleming, 2017, p. 46, 61 e 102)

Fleming demonstra, de uma forma cômica que antes a mulher era vista como inferior biologicamente e mentalmente doente, e ainda faz uma sátira para a falta de mulheres na história, principalmente, nos cargos de liderança. Há um deslocamento no tempo e nas formas de expressar o sexismo, mas a discriminação se mantém contra a mulher nos dias atuais. (2017, p. 102)

A campanha "Menos rótulos mais respeito" proposta pelas procuradoras de Goiás tenta quebrar os preconceitos que desqualificam e incapacitam a mulher como profissional, onde a sedução é vista como forma de ascensão profissional. Estas discussões ainda são sentidas em "brincadeiras" atuais como "belas, recatas e do lar" ou mesmo em estudos sobre as "áreas profissionais ditas femininas". (ALMEIDA, 2017, paginação irregular).

Expressões do tipo "bonita demais para ser inteligente", "histérica", "bonitinha, mas burra", "deve ser a TPM", "você deveria ser modelo e não estar num tribunal". O mérito nunca é conquistado pela sua capacidade profissional. A procuradora de Goiás Poliana Julião sofreu esse tipo de constrangimento quando era promotora de Justiça em Tocantins.

Ela conta que fez uma sustentação oral num processo difícil em segunda instância e conseguiu reverter a situação em favor do estado:

- Foi quando um colega me falou que eu ganhei porque o desembargador me achou bonita. Outro falou que eu tinha conseguido o cargo porque tinha prova oral no fim do concurso. Como se defender de uma ofensa dessa? (ALMEIDA, 2017, paginação irregular). 
Flávia Biroli fala em uma serie de vídeos ${ }^{14}$ produzida pela editora Boitempo sobre o seu livro gênero e desigualdades. Diz que sua obra esta situada num contexto brasileiro e que busca por meio de discussões sobre a desigualdade entre homens e mulheres tenta compreender o motivo que mantém o feminino inferior na sociedade, apesar de todos os avanços significativos. Trata também da posição desvantajosa e os limites impostos às mulheres. Afirma que as relações de gênero não se constituem de maneia isolada ao racismo e às vantagens de classe, situação que questiona os limites da democracia contemporânea.

Diz a autora em seu livro, no capitulo divisão sexual do trabalho, que esta divisão é uma questão de gênero, pois as mulheres ainda dedicam mais tempo aos trabalhos não remunerados (cuidado com outras pessoas e trabalho doméstico), trabalhos que só são pouco valorizados por guardar um registro de ser gratuito e realizado por mulheres como consequência do casamento. Diz ela que se visto por outra perspectiva estes trabalhos são fundamentais para o cotidiano. (2018, p. 21-22)

Esta pesquisadora nos leva a questionar por que a desvalorização de um trabalho fundamental não é transformado em um problema político central. Ela nos provoca questionando quem realiza os trabalhos sub-valorizados e quem estão nos cargos políticos e de liderança, e ainda, quem define a agenda pública. Segundo a escritora a sub-representação das mulheres na política institucional expõe esses limites. (Biroli, 2018, p. 23-24)

São elas apenas que fornecem esse tipo de trabalho gratuitamente, e sua gratuidade se define numa relação, o casamento. É nele que o trabalho gratuito das mulheres pode ser caracterizado como não produtivo. Os produtos que não têm valor quando decorrem do trabalho da mulher em casa passam, no entanto, a ter valor econômico fora da casa,

14 https://www.youtube.com/watch?v=vkTD-ddwhlQ 
quando atendem às necessidades de outras pessoas que não o marido. (BIROLI, 2018, p. 28 e 29).

Biroli nos lembra que a participação das mulheres na política é fundamental, pois se as mulheres não estiverem na política as suas demandas não serão politizadas e os problemas femininos não serão levados aos debates como problemas públicos de grande relevância, comprometendo a autonomia individual e coletiva das mulheres. (2018, p.171-175)

A desembargadora aposentada do Tribunal de Justiça do Rio Grande do Sul, Maria Berenice Dias, em seu texto, a solução para a desigualdade, quem melhor resume esta questão: $(1997$, p. 2)

Ao que se deve atentar não é à igualdade perante a lei, mas ao direito à igualdade mediante a eliminação das desigualdades, o que impõe que se estabeleçam diferenciações específicas como única forma de dar efetividade ao preceito isonômico consagrado na Constituição (DIAS, 1997, p. 2).

Platão em seu livro $V$, de a república, na sua sociedade utópica, diz que a mulher deve ser igualmente parte ativa na sua dinâmica e ocupar ao lado do homem guardião a função de guardiã dos bens da comunidade, e que homens e mulheres são seres equiparados, pois a alma é igual para homens e mulheres. Resumindo com isto, que caberia naturalmente, cargos de chefia para as mulheres, inclusive, lideranças femininas em grupo de homens. (2001, p. XXV)

Para Platão ${ }^{15}$ não há na administração da cidade nenhuma ocupação própria da mulher enquanto mulher, nem do homem, enquanto homem. 0 filosofo foi um visionário ao atribui à mulher pé de igualdade com o homem, quando se sabe que, em

15 Fundador da Academia de Atenas, Platão, aluno de Sócrates e professor de Aristóteles, é um dos filósofos gregos mais conhecidos. Com sua obra A República fundou a filosofia política ocidental. 
Atenas, por volta de 380 a.C., a mulher já era considerada como destinada ao lar e à educação dos filhos, e que não pertenciam ao grupo daqueles que recebiam a cidadania grega, bem como os estrangeiros ou os escravos. Platão é considerado por muitos como feminista ao libertar a mulher da preocupação com o lar e os filhos. (2001, p. 218 - 225)

Dizia Platão que "cada um deve executar a sua tarefa específica, de acordo com a sua natureza”, (453b) mas para Platão a natureza estava ligada aos dons \habilidades não a gênero. Também defendia a cultura para as mulheres e a igualdade ao acesso ao plano da formação. "Se, portanto, utilizamos as mulheres para os mesmos serviços que os homens, tem de se lhes dar a mesma instrução" (451e). (2001, p. 214)

Charlotte Gilman nos leva ao questionamento sobre os vários tipos de machismo, com os personagens masculinos de sua obra. Tem aquele em que o homem se considera superior as mulheres pela condição biológica, o que por "amor" considera as mulheres frágeis e as priva do trabalho, e ainda há os homens que não são machistas, que compreendem a capacidade das mulheres, mas que por comodidade e conveniência, preferem não se manifestar e deixar as coisas como estão. (2018, p.157)

Toda a devoção e renúncia que nossas mulheres dedicavam às suas famílias em particular, essas mulheres ofereciam ao seu país e à sua raça. Toda a lealdade e o trabalho que os homens esperavam de suas esposas, elas ofereciam, não apenas a homens, mas coletivamente umas às outras Gilman, 2018, p.168)

Na Organização das Nações Unidas, ONU Mulheres ${ }^{16}$, Entidade das Nações Unidas para a Igualdade de Gênero e o Empode-

16 A ONU Mulheres foi criada, em 2010, para unir, fortalecer e ampliar os esforços mundiais em defesa dos direitos humanos das mulheres. Possui seis áreas prioritárias de atuação: liderança e participação política das mulheres; empoderamento econômico; fim da violência contra mulheres e meninas; paz e segurança e emergências humanitárias; governança e planejamento; normas globais e regionais. 
ramento das Mulheres, se dedica a garantir os direitos humanos das mulheres no mundo, foram constituídos os princípios de empoderamento das mulheres que também beneficiam os homens ao institui um ambiente mais acolhedor e justo para todos. Traz como exemplo, a licença-paternidade estendida que beneficia os dois e quebra vários estereótipos, e causa novas referências para as novas gerações, a criança olha o homem e a mulher em posição de igualdade.

\section{A MULHER COMO UMA PROFISSIONAL NO MERCA- DO DE TRABALHO}

Esta seção tratará da ascensão das mulheres ao topo da carreira, suas conquistas e seus desafios para conciliar a vida profissional com a vida pessoal.

A Divisão sexual do trabalho e o acúmulo de funções, as ações afirmativas que estão sendo implantadas para garantir igualdade gênero. $\mathrm{O}$ quanto as mulheres assumirem posições de liderança acarretam mudanças na vida das outras mulheres e na sociedade. E a sororidade entre as mulheres.

\subsection{VIDA PESSOAL X VIDA PROFISSIONAL}

Quem faz o trabalho doméstico? Solange Simões ${ }^{17} \mathrm{e}$ Marlise Matos ${ }^{18}$ coletaram dados do Instituto Brasileiro de Geografia e Estatística (IBGE) 2006, e utilizaram a pesquisa do Instituto Universitário de Pesquisas do RJ (IUPERJ) 2003 e chegaram à conclusão de que há um paradoxo entre valores modernos e práticas tradicionais. A grande maioria dos pesquisados ainda acredita que o trabalho doméstico seja encargo da mulher ao

17 Solange Simões é professora associada e coordenadora do Grupo de Estudos de Gênero da Eastern Michigan University.

18 Marlise Matos é Professora Associada do Departamento de Ciência Política da Universidade Federal de Minas Gerais e Coordenadora do Núcleo de Estudos e Pesquisas sobre a Mulher - NEPEM e do Centro do Interesse Feminista e de Gênero - CIFG (UFMG). 
mesmo tempo em que concordam que a mulher além de contribuir para a renda da família, tem direito ao seu crescimento intelectual e profissional. Sendo assim as escritoras constataram desigualdade entre as próprias mulheres que ao invés de buscar um equilíbrio de gênero no trabalho doméstico se utilizam e até exploram outras mulheres, gerando um problema de diferença racial e de classe entre as próprias mulheres. "Até que ponto as mulheres de nível superior estão apoiadas nos trabalhos de empregadas domésticas e de babás para serem finalmente bem sucedidas em suas carreiras?" (SIMÕES; MATOS, 2010, p. 23).

Helena Rato coordenou um estudo feito pela administração pública central portuguesa que trouxe a igualdade de gênero como uma questão social central. Foram analisadas as necessidades de políticas para a promoção da igualdade de gênero e a pesquisadora constatou precisar haver uma amplitude transversal que integre, o planejamento urbanístico, a organização e gestão da rede escolar e o apoio a idosos para que se compatibilize o trabalho remunerado com a assistência à família e para que também se promova a mudança na representação do papel social e profissional do homem e da mulher. (2007, p. 87).

Rato em seu texto, a Valorização social do uso do tempo na promoção da igualdade de gênero, fala que o trabalho mais valorizado é o trabalho remunerado, e o trabalho não remunerado (cuidados à família e a casa) continua sendo compreendido como tarefa das mulheres. A escritora entende que há uma dicotomia, pois as mulheres perdem por ter menos tempo para se desenvolverem profissionalmente e participarem ativamente na vida pública, e os homens perdem de participar da vida familiar, principalmente da educação dos filhos, mantendo assim o modelo da desigualdade de gênero. Para a pesquisadora a queda da natalidade nos países mais desenvolvidos se deve ao custo em dinheiro e em tempo de criar uma criança e o fato das desigualdades de gênero penalizarem mais as mães do que os pais. Ela traz pesqui- 
sas que demonstram que "nos EUA, 25\% das mulheres em idade fértil não estão dispostas a ter filhos, subindo essa percentagem para 40\% no caso das mulheres afro americanas." (2008, p.07).

Países como Suécia e Dinamarca buscam por compensar as desigualdades com políticas públicas afirmativas de proteção à família (family-friendspolicy), como flexibilização dos horários de trabalho, licenças de parentalidade e investimento na educação e em serviços públicos para cuidar das crianças e dos idosos. $\mathrm{Na}$ Suécia foram criadas licenças exclusivamente para os pais, e estas licenças não pode ser transferidas para as mães. (Rato, 2008, p.11).

O sistema tributário ao não levar em conta à igualdade de gênero e tributar as mulheres como tributa os homens onera duplamente as famílias, pois acaba reduzindo o rendimento líquido desta família e encarecendo os custos com a aquisição de serviços de cuidados a crianças e idosos, dificultando a saída das mulheres para o mercado de trabalho. Esta mulher será questionada se compensa o estresse, a no mínimo dupla jornada, pois ela ganha menos, tem menos tempo para dedicar à vida profissional, tem um alto custo para ficar fora de casa e o quanto "ela faz falta no lar". Todas estas questões levam as mulheres ao dilema de se devem optar por não terem filhos ou a retardar ao máximo a maternidade e quando se tornarem mães desistem de investirem nas carreiras, ficando com cargos mais baixos, que não exijam tanta dedicação ou ainda parando de vez de trabalhar (Rato, 2008, p.11 - 12).

Para Marcelo do Carmo Rodrigues ${ }^{19}$ em sua aula na Unisino$\mathrm{S}^{20} \mathrm{o}$ que causa a barreira para a ascensão profissional é a quebra,

19 Atua como professor universitário na Unisinos, UNISC, La Salle e FSG, na graduação e pós, nas áreas de Economia e Finanças, Governança Corporativa, Gestão para Inovação, Liderança e Formação Executiva e coaching de executivos em empresas nacionais e multinacionais de grande porte.

20 Curso de extensão: liderança feminina: desafios e oportunidades, organizado por conexão IE. Ocorrido em 2 de out - 4 de out 2018. Campus Unisinos Porto Alegre. 
interrupção na carreira, e este obstáculo é tanto para as mulheres quanto para os homens. Ele explica que quanto mais tempo uma pessoa ficar fora do mercado de trabalho, mais baixa a função que irá desempenhar e como consequência, menor será o salário que lhe será oferecido. E para Rodrigues a maior desvantagem para as mulheres é que elas ficam mais tempo fora e por mais tempo, principalmente, por causa dos cuidados com pessoas da família e para ter filhos.

O Instituto Brasileiro de Geografia e Estatística - IBGE, com estes gráficos demonstra que dez anos depois da pesquisa supracitada pouca mudança ocorreu na divisão dos trabalhos domésticos por gênero.

Figura 1 -Pesquisa IBGE: Média de horas dedicadas aos cuidados de pessoas e/ou afazeres domésticos

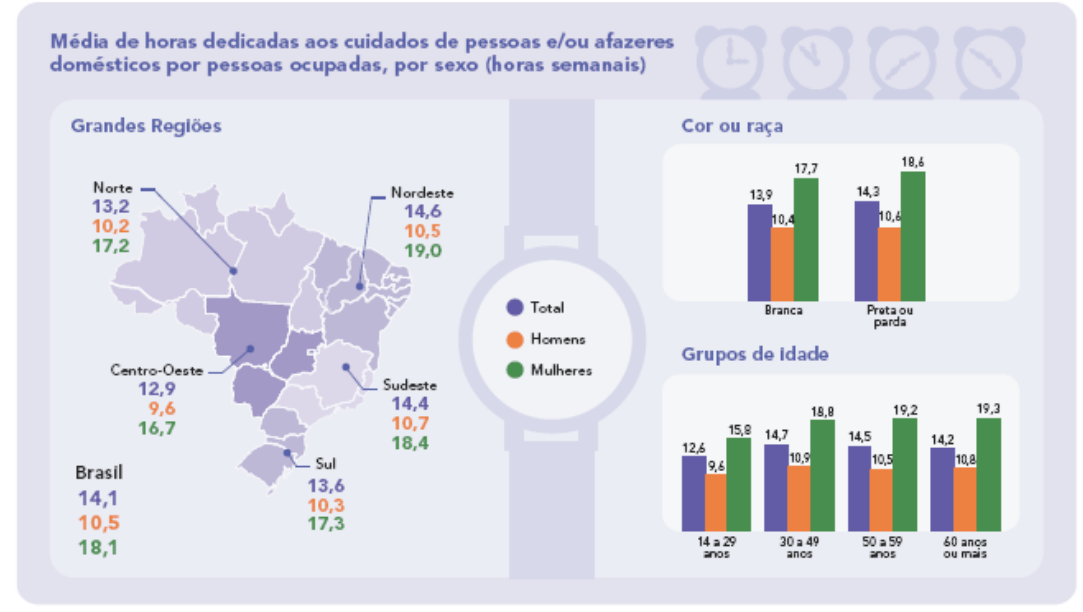

Fonte: IBGE, Pesquisa Nacional por Amoatra de Domizilias Contirua 2016.

IBGE, Informações atualizadas em 08.06.2018 21

A pesquisa da PlayScale ao entrevistar 2 mil pessoas concluiu que nas questões de família são as mulheres que mais necessitam

21 https://biblioteca.ibge.gov.br/visualizacao/livros/liv101551_informativo.pdf 
de períodos de afastamento. Por isto se fala hoje nas carreiras estéreis, que são aquelas que se houver esta interrupção na carreira ela será completamente perdida.

Figura 2 - Período de afastamento profissional
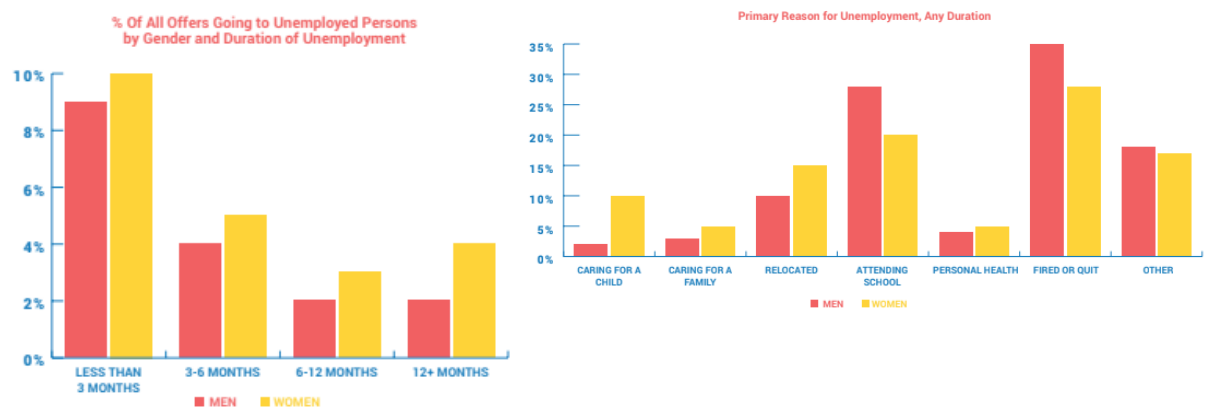

PlayScale ${ }^{22}$ O Status do Gap de gênero 2018. - Women are Still paid less into 2018.

A pesquisa também concluiu que as mulheres e homens param de trabalhar por motivos diferentes, enquanto as mulheres param para cuidar de pessoas da família, os homens param para se aprimorar, isto também impacta no retorno, já que os homens retornam mais qualificados e para cargos mais elevados, consequentemente, serão mais remunerados, enquanto as mulheres ficam desligadas da vida profissional, logo, desatualizadas, e retornam para cargos inferiores com salários mais baixos.

O Ministério Público (MP) através da subprocuradora Ela Wiecko lançou projeto que visa identificar o que causa a dificuldade da mulher alcançar os mais altos postos dentro do próprio MP. Na pesquisa realizada, Wiecko diz ter identificado que a organização da família impõe ônus às mulheres e acarreta um prejuízo social (WIECKO, 2018, paginação irregular).

22 PayScale, administradora de pesquisa salarial em tempo real. 
Por exemplo, as tarefas de cuidado com os filhos ou de administração da vida doméstica não são consideradas no cômputo das atividades produtivas da economia e não são consideradas como uma responsabilidade de impacto social. Atualmente, há casais que promovem mudanças na divisão do trabalho doméstico, mas isso ainda é insuficiente para uma alteração na estrutura da sociedade. (WIECKO, 2018, paginação irregular).

Wiecko, em junho de 2018, concluiu o plano de ação para transversalizar a perspectiva de gênero e étnico-racial, e constatou que no quadro de pessoal ${ }^{23}$ da ESMPU ${ }^{24}$ a maioria é constituída por mulheres (cargos de técnico administrativo), porém, nos cargos de direção a proporção se inverte. A subprocuradora cita como exemplo o Conselho Administrativo, CONAD, que se compõe de 9 membros e tem apenas duas mulheres. Também constataram que a maior parte dos cargos em comissão são ocupados por mulheres $(57,12 \%)$, mas são os homens que ocupam as funções de maior remuneração. (2018, p. 33 e 34).

$\mathrm{Na}$ equipe de estagiários as mulheres são a maioria com (55\%), e as empresas de serviços terceirizados a maior parte dos funcionários são do sexo feminino $(65,7 \%)$, nas funções de confiança são as mulheres que ocupam mais cargos $(61,29 \%)$ e também as funções mais altas. No quadro de docentes ${ }^{25} 1.935$ membros/as e servidores/as do MP exerceram atividades de docência, sendo 70,96 \% homens e 20,04 mulheres. Os discentes $50,15 \%$ masculina e $38,88 \%$ feminina e $11 \%$ não informaram. Dos 399 artigos publicados, 127 (32\%) são de autoria feminina e 270 (68\%) de homens. (2018, p. 37-57).

Wiecko faz uma distinção entre políticas públicas de gênero e políticas públicas para as mulheres. Sendo que as de gênero

\footnotetext{
23 Dados de março de 2018.

24 Escola Superior do Ministério Público da União

25 Período de 2015 a 2017.
} 
consistem em estabelecer a diversidade na sociedade, e as para mulheres estabelecem a visão de responsabilizar a mulher pela reprodução e educação dos filhos, e por demandas que garantam a manutenção e permanência da família e não o empoderamento e autonomia da mulher. E para políticas públicas de gênero são necessárias as produções e divulgações de pesquisas sobre as desigualdades de gênero e suas interseccionalidades, além de projetos que estabeleçam um diálogo constante com o movimento organizado de mulheres. (2018, p. 61-64).

Para Joyce Moisés o maior desafio das mulheres bem-sucedidas hoje é conseguir conciliar a carreira com a vida afetiva. As mulheres estão em busca de homens que também não se encaixem mais nos estereótipos de macho, provedor, insensível. Elas querem sucesso na sua carreira profissional e os seus espaços, para isto, precisam de parceria e de equilíbrio nos relacionamentos, caso contrário necessitaram escolher entre atingir o topo na sua carreira com constituir uma família. A maternidade é outro assunto delicado, pois pelo medo de perder tudo que lutaram tanto para conseguir vão adiando e esquecem-se do relógio biológico, e mulheres que tem o desejo da maternidade acabam se frustrando com esta perda, que faz parte da sua realização como pessoa. (2011, p.21-36).

Soraia Schutel na sua palestra da WLM, anteriormente citada, concorda com Joyce Moysés que as mulheres precisem de parceiros de vida para conseguir ser líder, a escolha do parceiro da vida pessoal faz parte das escolhas para atingir o objetivo profissional.

O “peso de ser uma família tradicional” é definidor de até onde a mulher pode chegar profissionalmente. A mulher tem que investir mais, provar mais, trabalhar mais e mesmo assim seu trabalho é menos valorizado, visto que persiste a semântica extremamente machista, no qual está pré-determinado que a mulher se dedique mais à família que o homem 
Cristiana Brito tem a visão de que a vida familiar versos a profissional seja apenas um dos muitos dilemas que tiram o sono e minam o futuro das mulheres. Para a escritora, a independência financeira, a realização profissional, o medo de enfrentar uma demissão, etc, são tão prejudiciais a vida profissional quanto a pressão do destino das gerações anteriores (que se dedicavam exclusivamente à casa e a família). Mas a escritora acaba caindo em contradição, pois cita exemplos de mulheres que abdicaram do seu desenvolvimento profissional para apostar na carreira do marido e também com seu próprio depoimento que narra só ter conseguiu ser uma líder por ter casado com um homem que aceitou "a troca de papeis". (2018, p. 17, 24-25)

Alessandra Gonzaga, em sua palestra na Unisinos ${ }^{26}$, concorda com Maitena que as responsabilidades femininas aumentaram no transcorrer das décadas, sem que as mulheres deixem de assumir os encargos anteriores, sofrem assim com o acúmulo de funções.

- Em 1920, nós, mulheres, só estávamos ansiosas por uma paixão...

- Em 1930, nós, mulheres, só estávamos ansiosas por uma paixão... e obcecadas por conseguir um bom marido...!

- Em 1940, nós, mulheres, só estávamos ansiosas por uma paixão, obcecadas por conseguir um bom marido... e preocupadas em ser boas mães...!

- $\quad$ Em 1950, nós, mulheres, só estávamos ansiosas por uma paixão, obcecadas por conseguir um bom marido, preocupadas em ser boas mães... e inquietas por estudar alguma coisa útil...!

- Em 1960, nós, mulheres, só estávamos ansiosas por uma paixão, obcecadas por conseguir um bom marido,

26 Curso de extensão: liderança feminina: desafios e oportunidades, organizado por conexão IE. ocorrido em 2 de out - 4 de out 2018. campus Unisinos porto alegre 
preocupadas em ser boas mães, inquietas por estudar alguma coisa útil... e transtornadas para participar de coisas interessantes!

- Em 1970, nós, mulheres, só estávamos ansiosas por uma paixão, obcecadas por conseguir um bom marido, preocupadas em ser boas mães, inquietas por estudar alguma coisa útil, transtornadas para participar de coisas interessantes... e culpadas por trabalharmos fora...!

- Em 1980, nós, mulheres, só estávamos ansiosas por uma paixão, obcecadas por conseguir um bom marido, preocupadas em ser boas mães, inquietas por estudar alguma coisa útil, transtornadas para participar de coisas interessantes, culpadas por trabalharmos fora... e estressadas por exigir-nos conquistas profissionais!!

- Em 1990, nós, mulheres, só estávamos ansiosas por uma paixão, obcecadas por conseguir um bom marido, preocupadas em ser boas mães, inquietas por estudar alguma coisa útil, transtornadas para participar de coisas interessantes, culpadas por trabalharmos fora... estressadas por exigir-nos conquistas profissionais... e desesperadas para nos vermos jovens, magras e sem celulite!! (MAITENA, 2003, v. 3, p. 76-77)

Maitena satiriza o acúmulo de funções, mostrando que as mulheres deixaram de ser submissas, mas perderam alguma coisa nesse caminho. Não que o trabalho doméstico não seja pesado e cansativo, mas o acumulo de compromissos, deixa as mulheres desgastadas, cansadas e sufocadas, limitando até onde elas podem chegar. (MAITENA, 2003, v. 5, p. 83)

Como sua vida muda no primeiro ano do bebê A primeira coisa que ele faz é ler o jornal.

A primeira coisa que ela faz é dar mamadeira. Quando ele sai para trabalhar, se sente... livre. 
Quando ela sai para trabalhar, se sente... culpada. Em seu tempo livre, ele vê futebol, lê ou conversa com os amigos.

Nos dela, ela se ocupa da roupa, do médico e do cabeleireiro... do bebê.

Ele sente mais falta do sexo.

Ela sente mais falta de dormir. (MAITENA, 2003, v. 5, p. 83).

A autora ainda nos faz refletir, em sua forma descontraída de passar as mensagens, sobre as responsabilidades em relação ao cuidado com os filhos que, de regra, sempre pesaram mais para as mães do que para os pais. (MAITENA, 2003, v. 5, p. 83).

Uma mulher ainda enxerga a ascensão profissional pela lente do sacrifício e não da realização, entretanto com autoconhecimento podem conseguir identificar o que é sucesso para si e com isso ser capaz de estruturar a sua vida de forma autentica para alcançar resultados profissionais e ao mesmo tempo ter qualidade nos relacionamentos. As mulheres não precisam abrir mão de nada, desde que tenham em mente que precisaram fazer escolhas baseadas nos objetivos que pretendem atingir, isto quer dizer que tudo precisa ser planejado com antecedência, desde o parceiro, os estudos e até o caminho dentro da carreira.

\subsection{EMPODERAMENTO FEMININO}

Todas as conquistas femininas refletem o contexto em que estamos vivendo hoje. 0 empoderamento feminino busca o fortalecimento de mulheres em prol de uma sociedade mais justa para as mesmas. De acordo com o dicionário Michaelis ${ }^{27}$, empoderamento é:

Ação coletiva desenvolvida por parte de indivíduos que participam de grupos privilegiados de

27 EMPODERAMENTO. In: DICIONÁRIO Michaelis. Disponível em: Acesso em 09/07/2018. 
decisões. Envolve consciência social dos direitos individuais para que haja a consciência coletiva necessária e ocorra a superação da dependência social e da dominação política. É um processo pelo qual as pessoas aumentam a força espiritual, social, política ou econômica de indivíduos carentes das comunidades, a fim de promover mudanças positivas nas situações em que vivem. Implica um processo de redução da vulnerabilidade e do aumento das próprias capacidades dos setores pobres e marginalizados da sociedade e tem por objetivo promover entre eles um índice de desenvolvimento humano sustentável e a possibilidade de realização plena dos direitos individuais. (EMPODERAMENT0,2018, paginação irregular).

Muitas são as lutas que o movimento feminista tem em sua trajetória, Mainara Oliveira e Verônica Teresi, narram em seu artigo ${ }^{28}$ as origens, marco destes movimentos das mulheres com a elaboração da "Convenção da Mulher", primeiro documento tratando de maneira minuciosa e ampla os direitos internacionais para erradicação da discriminação contra a mulher e da igualdade de gênero. Este movimento teve início na década de 70, com a ONU lançando a década da mulher. No Brasil a nova geração de garantias para as mulheres teve uma participação marcante com a constituição de 1988 ao visualizar um conjunto de reivindicações relativas ao seu processo de exclusão da mulher do meio público e da condição feminina de subordinação ao homem. (2017, p. 152).

Salete Silva conta na sua pesquisa ${ }^{29}$ que 26 deputadas $^{30}$ uniram-se para lutar pela inclusão dos direitos humanos para as

${ }_{28}$ Convenção da mulher: incorporação no Brasil e influência da sociedade civil.

29 O legado jus-político do lobby do batom vinte anos depois: a participação das mulheres na elaboração da constituição federal

30 Deputadas federais: Abigail Feitosa, Ana Maria Rattes, Benedita da Silva, Bete Azize, Bete Mendes, Cristina Tavares, Dirce Tutu Quadros, Eunice Michiles, Irma Passoni, Lídice da Mata, Lúcia Braga, Lúcia Vânia, Márcia Kubitschek, Maria de Lourdes Abadia, Maria Lúcia Araújo, Marluce Pinto, Moema São Thiago, Myriam Portela, Raquel Cândido, Raquel Capiberibe, Rita Camata, Rita Furtado, Rose de Freitas, SadieHauache, Sandra Cavalcanti, Wilma de Faria. 
mulheres e criaram o Conselho Nacional de Direitos da Mulher, CNDM, que ficou conhecido como Lobby do Batom e assim conseguiram garantir que as demandas das mulheres fossem recepcionadas na Constituição Federal. Tinham como lema: "Constituinte pra valer tem que ter palavra de mulher." (2008, p. 7).

Para a escritora os movimentos de mulheres foram ampliando-se, e consolidando-se, provando assim que é necessário haver mulheres na política para que se assegure cidadania às mulheres "o reconhecimento social e estatal de que as mulheres também têm direito a ter direito." (2008, p. 7).

A Salete nos faz refletir a importância de se compreender o direito como instrumento de empoderamento para as mulheres, dado que as mudanças nas leis solidificam as garantias conquistadas ao longo da história e permitem a evolução da sociedade. (2008, p. 3).

As mulheres foram sempre tratadas como "o belo sexo", algo para embelezar os ambientes políticos e públicos. E mesmo agora, com a constituição completando 30 anos ainda podemos ver a sub-representação feminina na política, mas estas mulheres demonstram com suas lutas e principalmente com suas conquistas, que "uma democracia sem mulheres é uma democracia incompleta". (Rocha ${ }^{31}, 2018$, p.27) e como disse Wilma Mankiller "O segredo do nosso sucesso é que nós, mulheres, nunca, nunca desistimos" (2018, paginação irregular). ${ }^{32}$

31 Maria Elizabeth Guimarães Teixeira Rocha, Ministra do STM /; https://www. editorajc.com.br/wp-content/uploads/2018/10/RJC_218.pdf

32 https://books.google.com.br/books?hl=pt-BR\&lr=\&id=ZSBxDwAAQBAJ\& $\mathrm{o} i=$ fnd \&pg $=$ PT 70 \& dq=carta + das + mulheres + brasileiras +aos +constituint es: $+30+$ anos + depois \&ots $=$ oHdvD8GFCN\&sig $=6$ wdNt-WUf2RXAFhWQ-K- o94fJIo\#v=onepage $\& \mathrm{q}=$ carta $\% 20$ das $\% 20$ mulheres $\% 20$ brasileiras $\% 20$ aos $\% 20$ constituintes $\% 3 \mathrm{~A} \% 2030 \% 20$ anos $\% 20$ depois $\& \mathrm{f}=$ false 
Figura 3 - Percentual de parlamentares mulheres

\section{Percentual de parlamentares \\ mulheres}

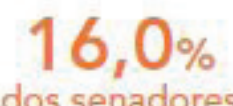

dos senadores
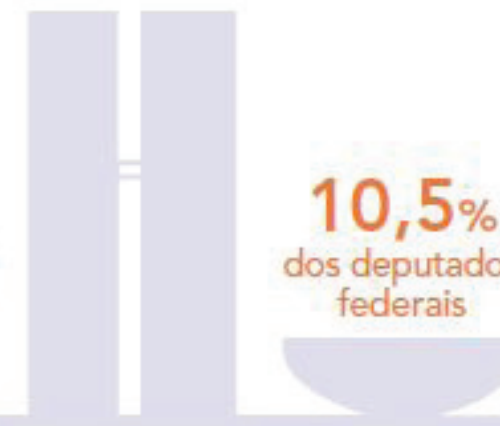

dos deputados

federais

Fonte: IBGE. Estatísticas de gênero. Indicadores sociais das mulheres no Brasil. $06 / 2018$

Figura 4 - Participação de mulheres nos cargos Ministeriais no governo Brasileiro

\section{$7,1 \% \begin{aligned} & \text { Participaçăo de mulheres nos cargos } \\ & \text { ministeriais do governo brasileiro }\end{aligned}$}

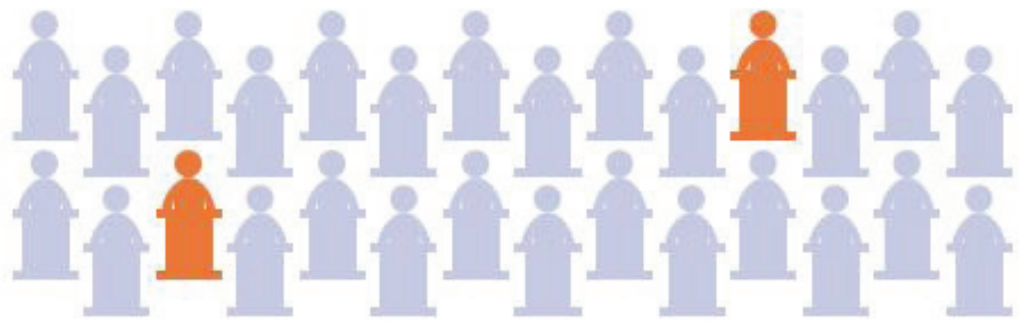

Fonte: IBGE. Estatísticas de gênero. Indicadores sociais das mulheres no Brasil. $06 / 2018$ 
Figura 5 - Vida Pública e tomada de decisão

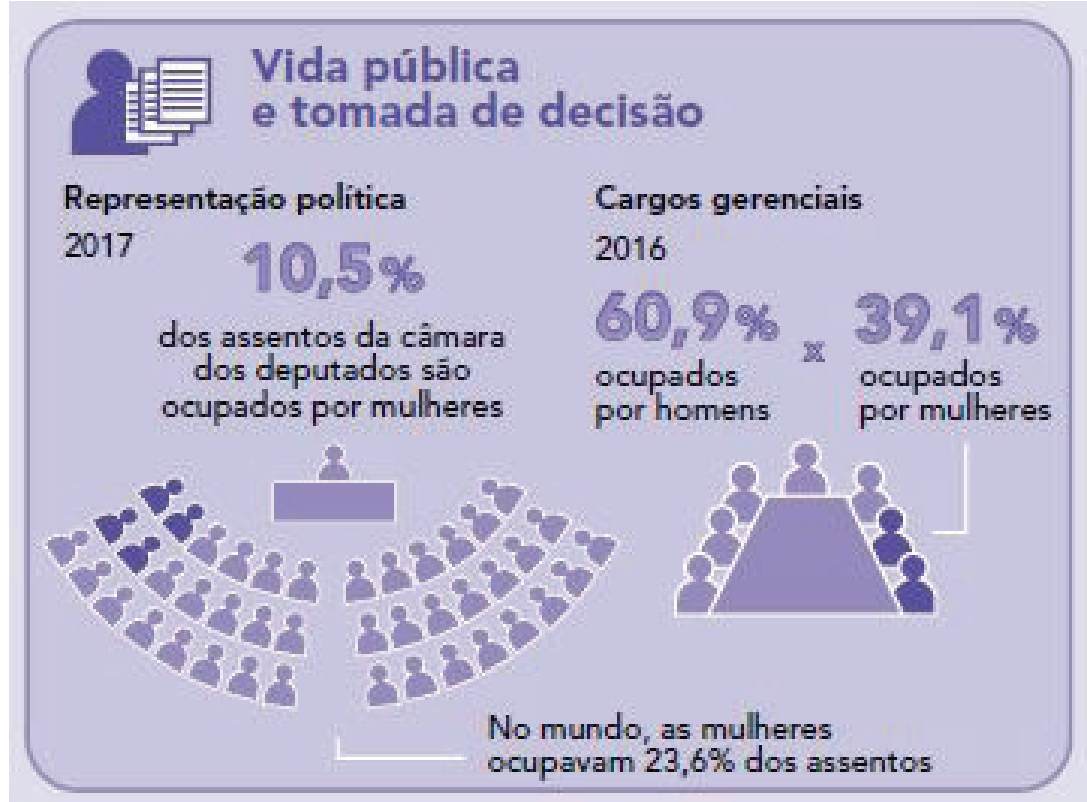

Fonte: IBGE. Estatísticas de gênero. Indicadores sociais das mulheres no Brasil. $06 / 2018$

O IBGE analisou as representações políticas por gênero e constatou que mesmo com a obrigação prevista pela Lei $\mathrm{n}^{\mathrm{o}}$ $9.504 / 97^{33}$, que estabelece em seu artigo $10^{\circ}$, parágrafo $3^{\circ}$, que cada partido ou coligação deve preencher, nas eleições proporcionais, o mínimo de $30 \%$ e o máximo de $70 \%$ para candidaturas de cada sexo, ficou demonstrado que os partidos não estão respeitando a lei. E ressalta uma "brecha" na referida norma, pois ela prevê a candidaturas em eleições proporcionais, mas não as vagas nas casas legislativas, e que não há sanção atribuída para o partido que deixe de cumpri-las. A falta de mulheres em exercício na política, segundo estudos eleitorais, pode ser atribuídas "a

33 Estabelece normas para as eleições. http://www.planalto.gov.br/ccivil_03/ leis/L9504.htm 
fatores como falta de apoio material às candidaturas femininas, inclusive no seio dos partidos políticos, e ao maior sucesso eleitoral dos candidatos que já eram parlamentares anteriormente" (2018, p. 9 e 10)

Para Helena Rato, a desigualdade de gênero, dentro das empresas públicas acontece de forma velada, pois as mulheres, apesar de serem maioria na base destas empresas, são minoria nos cargos de maior poder de decisão, sendo possível constatar uma segregação vertical e na perspectiva do gênero como categoria social, fenômeno de discriminação de gênero denominado de glassceiling, teto de vidro, ou seja, dificuldade de atingir cargos de maior responsabilidade. (Rato, 2007, p. 83).

As conquistas femininas trazem ganhos muito além do individual, principalmente as conquistas nas carreiras jurídicas públicas e políticas, uma vez que internalizam o valor da representatividade. São necessárias vozes femininas para garantir o direito feminino, e nas palavras de Solange Simões e Marlise Matos, ainda que a maioria das mulheres confie na sua capacidade de ocupar as posições de comando e liderança no país, pouco acesso lhes foi garantido. (2012).

As autoras em seu artigo ainda evidenciam as cotas para mulheres que depois de amplos debates no congresso nacional transformaram em quantidade mínima por gênero. Esta ação afirmativa ainda não foi capaz de diminuir a considerável ausência de mulheres nos postos do poder executivo, legislativo e judiciário em todos os níveis governativos (municípios, estados e união) (SIMÕES; MATOS, 2012).

Um estudo infográfico elaborado por Cristina Xavier de Brito nos mostra esquematizados marcos femininos e desta forma torna muito mais impactante os dados coletados. Passaram-se apenas poucas décadas desde que o país teve a sua primeira deputada, a primeira promotora de justiça, a primeira juíza, primeira senadora, primeira ministra, etc. Estas contribuições foram funda- 
mentais para a mudança no rumo da história e como nos mostra a própria escritora, possibilitaram o início da diversidade que é fundamental para criar uma organização, ou uma sociedade, mais sustentável. Destaca também a mentoria como uma prática que começa a ganhar força dentro das empresas, uma vez que ajudam as mulheres a pensar a partir da troca de experiências e apoio. (2018, p. 30-31).

As procuradoras de Goiás fizeram uma pesquisa ${ }^{34}$ e constataram que a desigualdade que está presente no setor público, que evidentemente é menor que no setor privado, no entanto, a distribuição dos cargos DAS por sexo deixa certo que o acesso das mulheres a níveis superiores é mais restrito. (ALMEIDA, 2017, paginação irregular).

Na administração pública, 39,7\% são mulheres. 0 que não acontece no topo. Os cargos comissionados, os chamados DAS (direção e assessoramento superior) têm uma exclusão sexual clara. No DAS 1 , que paga $R \$ 2.467,90$, as mulheres representam 44,9\%. Quando se vai para a outra ponta, o DAS 6, com salários de $\mathrm{R} \$ 15.479,92$, a participação da mulher cai para menos da metade: $21,7 \%$ : (ALMEIDA, 2017, paginação irregular).

Embora componham mais da metade da população, a mulheres são minorias expressivas no Congresso Nacional, em cargos de liderança nas Carreiras Políticas, do Judiciário, Ministério Público, na advocacia e também na academia. Em outras palavras, como disse Isabelle Glezer ${ }^{35}$ "as decisões importantes sobre suas vidas pessoais de profissionais das mulheres são tomadas pelos homens que exercem estas posições de poder". (2016, paginação irregular)

34 https://oglobo.globo.com/economia/mulheres-estao-em-apenas-37-dos-cargos-de-chefia-nas-empresas-21013908

35 https://www.jota.info/opiniao-e-analise/artigos/o-teto-de-vidro-da-advocacia-brasileira-29112016 
Sheryl Sandberg, a mais alta executiva do Facebook, formada em Harvard, já trabalhou para o Governo dos EUA e para o Google. É uma mulher que sem dúvida é o que todos poderiam chamar de empoderada. E ela conta que enfrentou desde o inicio de sua carreira até hoje as barreiras machistas, inconsciente e declaradas, pelas quais as mulheres que desejam cargos de liderança têm que enfrentar diariamente. Em seu livro Faça acontecer, encoraja as mulheres a sonharem alto, assumirem riscos e se lançarem em busca de seus objetivos sem medo. Ela explica que não é necessário que você se intitule feminista para entender as diferenças com que as mulheres são tratadas no dia a dia. (2013, p. XV)

Sheryl mostra com exemplos de mulheres que desistiram antes mesmo de começar, mas também com exemplos de outras que assumiram o desafio, e conduz a sua fala para estimular as mulheres a acreditarem em si mesmas e no seu potencial e desta forma perceberem que a única coisa que deve ficar para trás é justamente esse pensamento de auto sabotagem. (2013, p. 13)

Para a escritora a baixa autoconfiança das mulheres é um obstáculo interno que também se soma aos limitadores da ascensão das mulheres no mercado de trabalho. Cita exemplos mostrando que, enquanto os homens são promovidos com base no potencial que demonstram, as mulheres precisam apresentar realizações. (2013, p. 15)

Sheryl acredita que um maior número de mulheres na liderança levará a um tratamento mais justo a todas as mulheres. A escritora nos provoca ao incentivar as mulheres a negociar por si mesmas. Afirma que todos precisam aceitar mulheres em posições de liderança, inclusive as próprias mulheres. (2013, p. 72)

Chin-ning Chu, em seu livro a arte da guerra para mulheres, diz que as mulheres não se sentem à vontade para reclamar o poder por falta de prática e pelo treinamento \criação para buscar o poder de forma intermediada, como por exemplo, o casamento com homens poderosos, para ser a primeira dama, a rainha, etc. (2014, p. 87). 
A escritora lembra que poder não é dado, precisa ser exigido, que se toma posse. Com isto não é possível seguir o treinamento, ou ficar pedindo licença para ser poderosa, é necessário adotar medidas para fortalecer o poder pessoal. E para Chu, poder é capacidade de se desligar dos frutos das ações,é seguir a direção defina para fazer ou realizar propósitos e objetivos ligados a convicções. (2014, p. 88).

Simone de Beauvoir nos lembra:

Nunca se esqueça que basta uma crise política, econômica ou religiosa para que os direitos das mulheres sejam questionados. Esses direitos não são permanentes. Você terá que manter-se vigilante durante toda a sua vida. (Beauvoir,1967, p. 22 )

O processo de empoderamento feminino vai assumindo formas democráticas, construindo novos mecanismos de responsabilidades coletivas, de tomada de decisões e responsabilidades compartilhadas. (NEVES STREY, 2017, paginação irregular)

\subsection{FORMAS FEMININA DE GERENCIAR AMBIENTES DE TRABALHO}

Lacombe escreve que liderança é a capacidade de influenciar as outras pessoas para alcançar os objetivos estabelecidos, não é conseguir resultados através das pessoas, mas com as pessoas, buscando objetivos comuns que agradem tanto os líderes, quanto os liderados e as organizações. (LACOMBE, 2012, p. 245).

O líder empresarial deve ser capaz de alcançar objetivos por meio dos liderados e, para isso, conforme o tipo de liderado e a ocasião, age de diferentes maneiras: ele ordena, comanda, motiva, persuade, dá exemplos pessoais, compartilha os problemas e ações ou delega e cobra resultados,alterando a forma de agir de acordo com a necessidade de cada momento e com o tipo de liderado, visando alcançar os objetivos da empresa.(LACOMBE, 2012, p. 245). 
Grzybovski, Boscarin e Migott realizaram uma pesquisa com 26 mulheres em empresas familiares gaúchas sobre liderança feminina, concluíram que as mulheres apresentam estilo de liderança mais voltado para as pessoas do que para as tarefas eque cultivam valores como honestidade, apreciação do ser humano e companheirismo. São descritas como empregadoras de estilos mais rígidos e ao mesmo tempo promovedoras de ambientes mais acolhedores e de maior desenvolvimento de trabalho em equipe, aceitam mais rapidamente novas técnicas e experiências, e ainda são capazes de prever desafios, interagir com maior número de variáveis e projetar o futuro de forma estável. (2002, p. 206).

Já as pesquisadoras gaúchas em seu artigo definem que a mulher tem maior capacidade de criar empatia e colocar-se no lugar do outro, e ainda se mostra capaz de identificar problemas por antecipação. Contudo advertem que não significa dizer que a sua presença por si só é suficiente. A diversidade é extremamente importante e saudável, já que enquanto o homem tende à ação com menos opções, a mulher apresenta campo maior de investigação e gera múltiplas alternativas para solucionar um único problema. (2002, p.204)

Louann Brizendine, neuropsiquiatra americana, em seu livro, The Female Brain (Como as Mulheres Pensam) aponta as razões biológicas que demonstram como o cérebro feminino tem uma estrutura singular, permitindo assim ser possível determinar as prioridades de uma mulher, assim como se comunicam, o que pensam, o que gostam, etc. (2006, p. 21-24).

Brizendine revela que em seus estudos identificou que as mulheres conseguem traduzir sentimentos em palavras com maior rapidez e que possuem grande facilidade para interpretar expressões faciais. Com um simples olhar, percebem o que o outro está sentindo. Mulheres são capazes de desempenhar qualquer profissão, mesmo as tidas como masculinas. Mas, podem ter mais interesse em carreiras que exijam mais interação com outras pessoas, mais socialização. (2006, p.61-62). 
Chin-Ning Chu relata um pouco da história da cidade de Xian, berço da civilização chinesa. Conta a escritora que era uma sociedade Matriarcal altamente civilizada. As mulheres comandavam as reuniões e cumpriam todas as tarefas administrativas, herdavam as terras, tomam as decisões importantes e controlavam o seu dinheiro e os homens eram responsáveis pelas tarefas que exigiam força física. Esta era a posição das mulheres das civilizações chinesas, etruscas, cretenses, entre outras. A escritora nos deixa com a reflexão, se não seria possível que a natureza tenha designado ao homem os trabalhos braçais e as mulheres a administração e liderança, não só de suas casas, mas de suas sociedades? (2014, p. 15).

A escritora também acredita que a vitória sem confronto seja a nova batalha do feminismo, pois declarar-se vítima da discriminação masculina torna as mulheres vítimas, não vitoriosas, que declarar com palavras ou com ações amargura ou ressentimento pelos homens, cria obstáculos e as inimigas dos homens não são as executivas apreciadas nas hierarquias corporativas. Para ela, por mais que seja verdade a discriminação, a melhor forma de combatê-la é autoconfiança, acreditar que é igual a todos e superior na sua singularidade "em vez de insistir em lutar e brigar para alcançar a igualdade, declare, diga que é igual. Quando você fala, você é." (2014, p.156).

Chu cita vários exemplos de mulheres que tiveram ousadia e sensibilidade nos seus cargos de liderança e surpreenderam ao manter as características pessoais "e femininas" e ao mesmo tempo chamar a atenção, conseguir apoio para suas causas e revolucionar. "Encontre novas formas de marketing pessoal e tenha a coragem de expor alguma coisa bem diferente do que já foi feito." (2014, p.57).

A mulher se comporta como homem e se espelha nos modelos de lideranças masculinos até aprender que tem que ressaltar seus talentos femininos e perceberam que podem ter a sua pró- 
pria maneira de liderar e que, atualmente, estão sendo avaliadas como mais eficientes. $\mathrm{O}$ autoconhecimento é a força motriz da ação e realização de cada líder e a autenticidade é a palavra-chave para a líder alfa, pois as características deste estilo de liderança são ser empática, acessível, e inclusiva. Pesquisas mostraram que as lideres brasileiras possuem as seguintes características: profundo conhecimento, visão crítica e global do negócio, agilidade, determinação, humildade e equilíbrio emocional. E se sobressaltam dois perfis, aquelas que são mais racionais e especializadas em um assunto e aquelas que assumem um comportamento mais família dentro da organização, que cuidam e se preocupam com o todo.

\begin{abstract}
um líder deve ter habilidades de interpretar objetivos e missões, de estabelecer prioridades, de planejar e programar atividades em equipe, facilidade em solucionar problemas e conflitos e habilidade de delegar responsabilidades aos outros, para ter qualificações e ser capaz de ser um bom líder. (Chiavenato, 2004, p. 451 e 452).
\end{abstract}

Zenger e Folkman ${ }^{36}$ analisam a eficácia das mulheres como líderes. Em seu estudo concluíram que a liderança feminina se destaca, uma vez que as mulheres são melhores avaliadas em comparação aos homens pelos seus chefes, pela equipe de trabalho e pelos seus clientes. A inteligência emocional é apontada como característica fundamental dado que há um crescente entendimento que a qualidades do líder estão cada vez mais voltadas para a capacidade de gerir pessoas. As mulheres também apresentam maior destaque e aprovação quanto maior o cargo que ocupam. (2012, paginação irregular)

36 Jack Zenger é o CEO e Joseph Folkman é o presidente da Zenger / Folkman, uma consultoria de desenvolvimento de liderança. Eles são coautores do artigo de outubro de 2011 da HBR, "Making Yourself Indispensable”, e do livro How to Be Exceptional: impulsione o sucesso da liderança ampliando seus pontos fortes (McGraw-Hill, 2012). 
As características vistas como das líderes femininas são a capacidade de desenvolver outras pessoas, a inspiração e a motivação de outras pessoas, a construção de relacionamentos, a colaboração e o trabalho em equipe. Além disto, as mulheres foram vistas como mais eficazes em motivar, sendo exemplos e entregando resultados. Essas habilidades descrevem líderes que enfrentam e superam obstáculos complexos, e que lideram pessoas com integridade para atingirem resultados desafiadores.

Figura 6 - Cargos ocupados
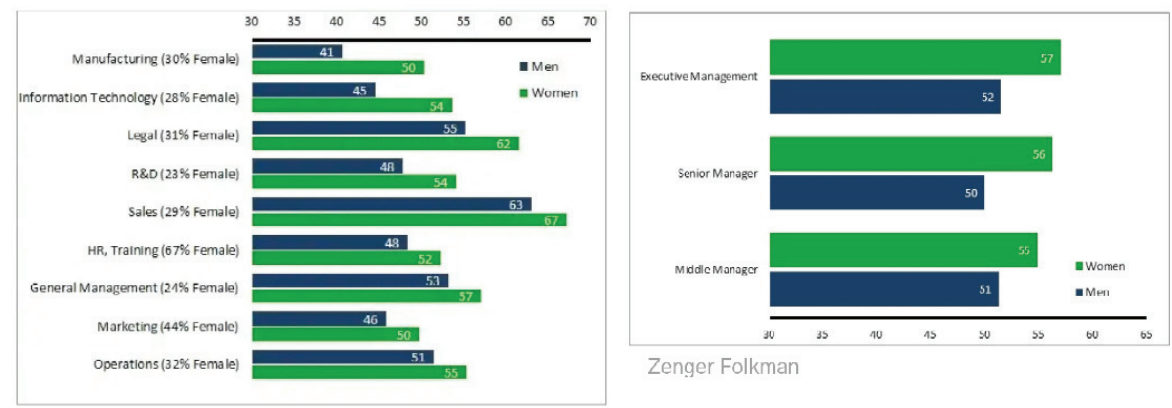

Zenger Folkman

Fonte: ZenglerFolkman

Carl Ranson Rogers, em seu livro Tornar-se Pessoa, analisa o conceito de pessoas responsáveis não só pelo seu papel individual, mas o dever de ser cidadão e de ajudar as pessoas que estão ao seu alcance a desenvolver-se permitindo construir sua vida de forma construtiva, inteligente, conseguindo socializar-se de forma mais satisfatória. "Como posso proporcionar uma relação que essa pessoa possa utilizar para seu próprio crescimento pessoal?" (ROGERS, 2009, p. 36)

"Se posso proporcionar um certo tipo de relação, o outro descobrirá dentro de si mesmo a capacidade de utilizar aquela relação para crescer, e mudança e desenvolvimento pessoal ocorrerão". (ROGERS, 2009, p. 37) 
A própria sociedade, através de seus líderes, poderia criar ambientes promissores e fazer com que os indivíduos alcancem sua autenticidade e busquem sua auto-realização. È nesta linha de pensamento que as mulheres se encaixam. Atualmente as empresas buscam líderes que consigam desenvolver ao máximo sua equipe, sentir o mercado, prever (com um sexto sentido) os problemas.

Dados mostram que das 16 competências analisadas as mulheres se destacaram em 12, inclusive em iniciativa e impulsionamento de resultados, que se acreditava que eram pontos fortes da liderança masculina. As mulheres foram consideradas grandes líderes por serem capazes de trazerem as habilidades pessoais para a liderança profissional tornando o ambiente mais acolhedor. A líder feminina se preocupa com a equipe, como está o desempenho no trabalho e como estão equilibrando a vida pessoal e profissional. Também são mais pró-ativas em se tornarem mentoras. (2012, paginação irregular)

Figura 7- Competências

\begin{tabular}{|c|c|c|c|c|}
\hline Leadership Competencies & Male & Female & $\mathbf{t}$ & Sig. \\
\hline Takes Initiative & 49.8 & 56.4 & 13.07 & 0.00 \\
\hline Uisplays High integrity and Honesty & 49.9 & 54.7 & -9.18 & 0.00 \\
\hline Drives for Results & 50.6 & 55.2 & 9.53 & 0.00 \\
\hline Practices Self-Development & 51.3 & 50.0 & 9.51 & 0.00 \\
\hline Develops others & 51.1 & 35.1 & 8.14 & 0.00 \\
\hline Inspires and Motivates uthers & 51.6 & 55.1 & -1.35 & 0.00 \\
\hline Builds Relationships & 51.2 & 59.5 & -6.70 & 0.00 \\
\hline Sonllaburat isun and Teamwork & 32.1 & 34.3 & -4.96 & 0.00 \\
\hline Champions Change & 51.6 & $5-1.0$ & -4.96 & 0.00 \\
\hline Fstahlishes Stretch Goals & 51.1 & 54.1 & -4.77 & 0.00 \\
\hline Solves Problems and Analyzesissues & 52.0 & 52.7 & -1.38 & 0.17 \\
\hline Communicates Powerfully and Prolifically & 52.9 & 53.4 & -1.14 & 0.26 \\
\hline Connects the Group to the Outside World & 52.3 & 52.1 & 0.34 & 0.73 \\
\hline Inmorates & 52.6 & 52.2 & 0.96 & 0.34 \\
\hline Tecturnical ar Prolessional Fxper lise & 52.1 & 51.1 & 2.10 & 0.04 \\
\hline Develops strategic perspective & 53.7 & 51.2 & 5.00 & 0.00 \\
\hline
\end{tabular}


Joanna Burigo, na palestra do SINTRAJUFE, falou que as mulheres fazem grandes revoluções sem derramar sangue. E reforçou esta ideia lembrando que não existe nenhum registro de morte nas revoluções feministas, elas são articulações pautadas em movimentos e projetos e se opõem opressões históricas. "A violência é patriarcada". (2018, paginação irregular)

\subsection{DIFICULDADES na advocacia}

As mulheres já são maioria na advocacia, entretanto não conseguiram alterar a lógica masculina com que ela foi construída, ficando as mulheres concentradas nos estágios iniciais da carreira.

Judy WAJCMAN ${ }^{37}$ nos traz que existe considerável literatura, principalmente estrangeira, que aborda as barreiras invisíveis "de vidro" a que os membros dos chamados "grupos minoritários", como mulheres e negros, encontram para ascender nas estruturas organizacionais, fenômeno costumeiramente designado de segregação vertical. (1998, p. 22)

A advogada Isabelle Glezer realizou uma pesquisa nos maiores escritórios de advocacia do Brasil juntamente com o Impulso Beta; startup que busca soluções na área da educação para promover liderança feminina e igualdade de gênero no mercado de trabalho. (2016, paginação irregular)

Nesta pesquisa a advogada diz que a falta de mulheres nas posições de liderança sempre lhe foram passadas como um fato natural da vida "Mulheres engravidam", "mulheres querem se dedicar às suas famílias", "mulheres são menos ambiciosas". Embora componham mais da metade da população, a mulheres são minorias na política, nos cargos de lideranças das grandes empresas e na advocacia não foi diferente, nos últimos anos tem

37 Judy Wajcman é o professora de sociologia Anthony Giddens, da Escola de Economia e Ciência Política de Londres. Ela é professora visitante no Oxford Internet Institute. Seus interesses acadêmicos englobam a sociologia do trabalho, estudos de ciência e tecnologia, teoria de gênero e análise organizacional 
se convertido numa profissão cada vez mais feminina eapesar do grande volume de mulheres nos quadros dos escritórios, o cenário se inverte quando se analisa o topo da cadeia. (GLEZER ,2016, paginação irregular)

Esta realidade foi o que Glezer chamou de "Teto de vidro" na advocacia brasileira, "a barreira invisível que impede que mulheres de alcancem posições de liderança em suas respectivas carreiras". Com justificativas estereotipadas e misóginas como o desejo das mulheres por uma vida mais tranquila para a maternidade ou ainda a falta de ambição das mulheres. Mas o que seu estudo realmente concluiu foi que as mulheres são avaliadas de forma mais severa, e mesmo assim são menos promovidas do que os homens. Mulheres ainda recebem menos do que homens com a mesma formação e experiência, e tendem a negociar menos aumentos e promoções com seus superiores. (2016, paginação irregular)

Na visão de Glezer existe ainda o receio de que convites para jantares de negócios, viagens de trabalho e até suas promoções serem mal interpretadas.

\footnotetext{
Muitas são as ações que os escritórios podem lançar mão para promover liderança feminina, diversidade e igualdade de gênero. 0 primeiro para esse trabalho é o tamanho do desafio que eles têm à frente. Ao olhar os números de nosso levantamento, a percepção é de que precisamos aproximar mais dois números bastante simbólicos: os $60 \%$ da participação feminina na base dos escritórios e os 30\% nas posições decisórias. (GLEZER ,2016, paginação irregular)
}

No que diz respeito à advocacia, Glezer constata que as mulheres têm menos oportunidades de networking e captação de clientes, fator decisivo na grande maioria dos escritórios para que um advogado se torne sócio. (2016, paginação irregular) 
Assim também nos fala Patrícia Tuma Martins Bertolin que atribui à escassa presença feminina nas cúpulas das empresas à existência de um telhado de vidro, que bloqueia as mulheres de ascender na hierarquia organizacional. Diz ainda a escritora que as sociedades de advogados também passam por este fenômeno e os homens acabam se tornam sócios com mais frequência do que as mulheres e aquelas que chegam ao topo dessas organizações ainda são tidas como "excepcionais". (2017, paginação irregular)

Na busca de refletir o papel de liderança da mulher e sua inserção nas instituições públicas, nas $\mathrm{OAB}$ e na política, a Escola Judiciária Eleitoral do Tribunal Regional Eleitoral do RS; Escola Superior da Advocacia da OAB/RS, e Comissão da Mulher Advogada da $\mathrm{OAB} / \mathrm{RS}$, lançaram o livro Mulheres no Poder, a obra condensa em formato de narrativas individuais as trajetória e realidade de vida, destas profissionais, mostrando as inúmeras adversidades e entraves culturais e sociais que enfrentam para atuarem nos cargos que ocupam.

Nesta mesma linha foi criada a Women in Law Mentoring, $\mathrm{WLM}^{38}$, quatro advogadas (Ana Amélia Ramos Abreu, Ana Paula Yurgel, Raquel Stein e Ana Carolina Tavares Torres) reuniram-se para buscar formas de unir e qualificar as mulheres, principalmente, da área jurídica. Esta associação ainda promove palestras em empresas e associações, esclarecendo e expondo as vantagens do empoderamento feminino e da diversidade para o espaço corporativo. (Projuris ${ }^{39}, 2017$, paginação irregular)

Neste projeto as mentoras (advogadas mais experientes) orientam as mentoradas (advogadas com até 5 anos de formação

38 O WLMBR é uma associação sem fins lucrativos cujo objetivo é promover o desenvolvimento continuado de advogadas, estimulando a criação de futuras lideranças femininas. 0 grupo promove anualmente um programa de mentoria, bem como cursos de aperfeiçoamento pessoal e profissional. www.facebook.com/womeninlawmentoring

39 ProJuris é um software jurídico online com chatbot que possui inteligência artificial integrado. 
em Direito) que como seu início de suas carreiras, uma espécie de apadrinhamento profissional, por meio de dicas que vão desde questões cotidianas do dia a dia jurídico, como melhoria de produtividade, identificação de tendências da área, redação e gerenciamento de redes sociais e até aspectos emocionais, como autoconfiança, tudo com o intuito de impulsionar a carreira da nova geração para que ultrapasse o já citado "teto de vidro". (Projuris, 2017, paginação irregular)

A WLM ainda realiza pesquisas, e irá apresentar até o final de novembro de 2018 os resultados da pesquisa que aplicou aos escritórios com atuação no sul e no sudeste, listados nas últimas edições Chambers\& Partners (2018) e Análise Advocacia (2017). Buscam proporcionar dados concretos e específicos sobre o número de mulheres na advocacia, sua participação em sociedades de advogados, como elas estão na evolução na carreira, e eventuais iniciativas voltadas à diversidade de gênero. (facebook, 2018, paginação irregular)

O International Steering Committe e do Women the Profession da organização Vance Center for International Justice ${ }^{40}$, entidade internacional ligada à ordem dos advogados de Nova Iorque (EUA), coordena uma rede de apoio aos advogados para construir engajamento global entre os advogados e para contribuir com a mudança social. Eles têm o Women in the Profession Program (WIP), um programa para desenvolver e fortalecer o crescimento das mulheres na profissão jurídica, procurando melhorar a inclusão da diversidade em todos os níveis da advocacia, com ênfase na liderança, tanto individual quanto a profissional. Em acordo com o esforço do Vance Center, são realizados projetos que promovem o status das mulheres que enfrentam situações vulneráveis, utilizando as leis para melhorar e garantir igualdade na sociedade para todas as mulheres. O WLM-BR é parte da Vance Center. (2018, paginação irregular)

40 O Centro Vance promove a justiça global ao envolver os advogados.https:// www.vancecenter.org/our-programs/women-in-the-profession/ 
Joseph Campbell em seu livro, o poder do mito, já dizia que o objetivo da vida passa a ser construir um sistema que me permita viver no campo oferecido pela sociedade que efetivamente sustente quem eu desejo ser. (1990)

As mulheres, ao longo da história, têm buscado por igualdade de gênero, contudo, de regra, são as mulheres que estão na profissão jurídica e na política que acabam por solidificarem as mudanças tão reivindicadas pelas mulheres. Nos órgãos públicos (são criados núcleos que elaboram pesquisas para compreender e combater as desigualdades) na política buscam desenvolver projetos de leis para garantir, pelo menos, o mínimo de representação feminina nos espaços corporativos e nos cargos de liderança da sociedade.

Não podemos deixar de lembrar que na advocacia estadual tivemos em 1989, a primeira, e até hoje, 2018, a única mulher a assumir a presidência da Ordem dos Advogados do Brasil do Rio Grande, Dra. Cléa Anna Maria Carpi da Rocha, e na advocacia federal ainda não tivemos uma presidente mulher, fato extremamente triste e preocupante, uma vez que a $\mathrm{OAB}$ já possui registrado em seu quadro, maioria feminina.

\subsection{ASCENSÃO NA CARREIRA}

A revista TIME elaborou o projeto Firsts $^{41}$, que apresenta entrevistas com 46 mulheres que foram as pioneiras a conquistar o topo das suas carreiras e apresenta o "She broke the glass ceiling." Para fazer as pessoas refletirem na imagem distorcida que usamos para as mulheres que atingem o seu sucesso profissional, definindo a realização em termos da barreira em vez do triunfo. Mulheres como por exemplo: Madeleine Albright, a primeira mulher a se tornar secretária de Estado dos EUA;Danica Roem, a primeira mulher abertamente transgênero a ser eleita e uma legislatura estadual dos EUA; Hillary Rodham Clinton, a

41 http://time.com/collection/firsts/ 
primeira mulher a ganhar a nomeação de um grande partido para presidente no EUA; Loretta Lynch, a primeira mulher negra a se tornar Procurador Geral dos EUA, etc. (2018, paginação irregular)

Nancy Gibbs, editora-chefe da TIME, a primeira mulher a ocupar essa posição, diz que o objetivo do projeto é registrar em livro os exemplos de mulheres de sucesso que estão mudando o mundo para que sirvam de motivação e inspiração para outras mulheres. A revista ainda incentiva as suas leitora a usarem as redes sociais, pelo \#SheIsTheFirst, para divulgar as mulheres importantes nas suas vidas e ampliar a divulgação das conquistas das mulheres. (2018, paginação irregular)

Cristiana Xavier de Brito, com seu livro, Mulher Alfa liderança que inspira, traz o perfil de dez líderes, mulheres brasileiras contemporâneas que se destacaram em sua autenticidade, criatividade e resiliência para liderar sua vida pessoal e profissional. Dá voz a mulheres em diferentes campos de atuação, abre um diálogo sobre os dilemas das brasileiras do século XXI e que servem como fonte de inspiração para as presentes e para as futuras líderes deste país. Mulheres como: Márcia Rocha, a primeira advogada travesti a atuar com o nome social registrado na OAB; Mara Gabrilli, a primeira vereadora, deputada federal e agora senadora tetraplégica da história do país; Valéria Scarance, promotora de justiça especializada em gênero e enfrentamento à violência contra a mulher; etc. (2018, p. 93, 101 e 132)

Uma autobiografia que traz uma leitura emocionante da luta de uma mulher para realizar seu sonho de ser advogada é o livro Feia, de Constance Briscoe, e nele ela não só consegue superar seus obstáculos, como vai muito além, torna-se juíza e uma das primeiras mulheres negras a presidir uma sessão de um tribunal no Reino Unido. (2009, contracapa)

Outro livro esplêndido é a ciranda das mulheres sábias, da psicanalista e escritora Clarissa Pinkola Estés, que trabalha com a ideia de sororidade. A autora revisita as histórias onde as jovens 
não são salvas por príncipes encantados, mas salvam a si mesmas depois de receberem orientação de uma personagem mais velha. O livro mistura experiências pessoais com relatos familiares e garante muito material para reflexão. "por todas as filhas e velhas que apóiam o que é bom e afastam a obediência cega a qualquer super cultura que premie somente a forma nivelada e deprecie o pensamento". (2007, p. 105)

A proposta do livro "Mulheres Incríveis", da escritora Kate Schatz conta com 44 mulheres, que se destacam em diversas áreas, desde a o esporte até a educação. A obra nos conduz por uma viagem Histórica por todos os continentes e nele nos deparamos com a história de mulheres grandiosas, empoderadas e inspiradoras. Livros como este nos possibilita enxergar a história de luta, coragem e determinação de mulheres que são mulheres reais, que fazem parte do nosso cotidiano e que possuem um trabalho incrível e que na maioria das vezes, invisíveis aos nossos olhos. Os perfis das brasileiras foram escrito por Jules de Farias, da ONG Think Olga, que contou a trajetória das mulheres como: Elza Soares, Marta, Débora Diniz, Maria da Penha e Sonia Bone Guajajara. (2017, p. 50 - 59)

\section{CONCLUSÃO}

A partir da pesquisa realizada, analisando-se as informações bibliográficas, é possível concluir que, embora as mulheres sejam a maioria da população e ocupem mais espaço no mercado de trabalho, ainda enfrentam muitas dificuldades para conseguirem assumir os cargos de liderança. Apesar de se qualificarem e se prepararem acadêmica e profissionalmente para assumir os postos de comando, muitas não encontram as oportunidades esperadas, porque o mercado de trabalho permanece sexista para os postos de comando, sendo associado aos homens o perfil para comandar, chefiar e liderar. Nesse sentido, as próprias mulheres estão desconstruindo a lógica perversa que predomina 
no mundo corporativo que impedem as mulheres de ascender profissionalmente.

Viemos de uma cultura patriarcal, de aspectos culturais problemáticos, que ainda se refletem nos dias de hoje. As mulheres ainda ganham menos que os homens, as mulheres ainda dedicam muito mais tempo com cuidados de pessoas da família e com os afazer domésticos que os homens, consequentemente, acabam dando espaço para que o homem se desenvolva, conquistando posições de liderança com mais facilidade.

As mulheres estão unindo-se e fortalecendo-se, com isto, estão mostrando o quanto a diversidade é positiva para os ambientes profissionais. E estão provando que as características, tidas como femininas, e que eram vistam tão negativamente, na verdade são um diferencial para gerir as equipes, fazendo com que as mulheres sejam melhores avaliadas nas pesquisas.

O chamado teto de vidro, como vimos neste artigo, já está sendo rompido e apesar das barreiras que as mulheres ainda enfrentam, o modelo antigo de mercado de trabalho não é mais sustentável. Na política ainda presenciamos a subrepresentação feminina e o desrespeito às leis que garantem o mínimo de participação das mulheres. E, embora seja verdade que as mulheres tendem a ser menos dispostas a acordos e a participar de jogos corporativos, as mulheres empoderam-se e conseguem com a sua sensibilidade, que é a nova tendência de mercado, desenvolver equilíbrio e elevação na autenticidade institucional.

São tantas grandes revolucionárias inspiradoras que já deixaram suas marcas e suas mensagens para as novas gerações de mulheres que é muito difícil eleger uma ou a melhor para o fechamento da pesquisa, mas escolhi a nossa revolucionaria farroupilha, Anita Garibaldi:

\footnotetext{
“Não tenha medo de viver, de correr atrás dos sonhos. Tenha medo de ficar parado." (1821-1849)
} 


\section{REFERÊNCIAS}

ALMEIDA, Cássia. Mulheres estão em apenas 37\% dos cargos de chefia nas empresas. 0 Globo, 2017. Disponível em: <https://oglobo. globo.com/economia/mulheres-estao-em-apenas-37-dos-cargos-de-chefia-nas-empresas-21013908>. Acesso em: 13 junho 2018.

BEAUVOIR, Simone de. 0 Segundo Sexo. 2. ed. São Paulo: Difusão Européia do Livro, 1967.

BERTOLIN, Patrícia Tuma Martins. Feminização da advocacia e ascensão das mulheres nas sociedades de advogados. Cadernos de Pesquisa v.47 n.163 p.16-42 jan./mar. 2017.Disponível em:<http:// www.scielo.br/pdf/cp/v47n163/1980-5314-cp-47-163-00016.pdf>. Acesso em: 13 junho 2018.

BIROLI, Flávia. Gênero e desigualdades: os limites da democracia no Brasil. São Paulo: Boitempo, 2018.

BRISCOE, Constance. Feia: A história real de uma infância sem amor. Rio de Janeiro: Bertrand Brasil, 2009. Tradução Caetano Waldrigus Galindo.

BRITO, Cristiana Xavier de. Mulher alfa: liderança que inspira. Belo Horizonte: Letramento Alpha Business, 2018.

CHAVES, Ricardo. Almanaque gaúcho. Jornal Zero Hora. Porto Alegre, 30 de agosto, 2018. ano 55. n. 19.180, p. 44)

CHIAVENATO, Idalberto. Administração nos novos tempos. Rio de Janeiro: Elsevier, 2004

CHU, Chin-Ning. A arte da guerra para mulheres.2.ed. São Paulo, SP: Fundamento Educacional, 2014.

DE GÊNERO, IBGE Estatísticas. Indicadores sociais das mulheres no Brasil. Estudos e Pesquisas-Informação Demográfica e Socioeconômica, n. 38, 2018.

ESTÉS, Clarissa Pinkola. A ciranda das mulheres sábias. São Paulo: Rocco, 2007.

DIAS, Maria Berenice. Ações afirmativas: a solução para a desigualdade. Porto Alegre, 2018. Disponível em: <http://www.mariaberenice.com.br/ manager/arq/(cod2_748)3_acoes_afirmativas_a_solucao_para_a_desigualdade.pdf $>$. Acesso em: 13 junho 2018.

FLEMING, Jacky. Qual o problema das mulheres? Porto Alegre: L\&PM, 2018. 
FONTANELE-MOURÃO, Tânia; GALINKIN, Ana Lucia. O que pensam as mulheres no topo da carreira? In: ARAUJO, Adriane Reis de; FONTENELE-MOURÃO, Tânia (Org.). Trabalho de mulher: mitos, riscos e transformações. São Paulo: LTR, 2007. 245 p. Cap. 10

GILMAN, Charlotte Perkins. Herland: a terra das mulheres. Rio de Janeiro: Rosa dos Tempos, 2018.

GLEZER, Isabelle. 0 teto de vidro da advocacia brasileira. JOTA. Disponível em: < https://www.jota.info/opiniao-e-analise/artigos/o-teto-de-vidro-da-advocacia-brasileira-29112016>. Acesso em: 13 junho 2018.

Grzybovski,Denize; Boscarin Roberta; Migott, Ana Maria Bellani. Estilo feminino de gestão em empresas familiares gaúchas. Revista de Administração Contemporânea. vol. 6 no.2 Curitiba May/Aug. 2002.Disponível em: <http://dx.doi.org/10.1590/S1415-65552002000200011 >. Acesso em: 13 junho 2018.

IBGE, Coordenação de População e Indicadores Sociais. Estatísticas de gênero: indicadores sociais das mulheres no Brasil.Rio de Janeiro. 2018. Disponível em:<https://biblioteca.ibge.gov.br/index.php/biblioteca-catalogo?view=detalhes\&id=2101551>. Acesso em: 15 outubro 2018.

KEHL, Maria Rita. Deslocamentos do feminino. Rio de Janeiro: Imago, 1998.

KEHL, Maria Rita. Palestra Deslocamentos do Feminino: A mulher freudiana na passagem para a modernidade. Instituto Vox, 20/ago., 2014. Disponível em: <https://www.youtube.com/watch?v=o1yDVuY77Bc>. Acesso em:17 outubro 2018.

LACOMBE, Francisco José Masset. Recursos humanos princípio e tendência. São Paulo: Saraiva, 2012.

MAITENA, Inés Burundarena. Mulheres Alteradas 1. Rio de Janeiro: Rocco, 2003. Tradução de Ryta Vinagre.

MAITENA, Inés Burundarena. Mulheres Alteradas 2. Rio de Janeiro: Rocco, 2003. Tradução de Ryta Vinagre.

MAITENA, Inés Burundarena. Mulheres Alteradas 3. Rio de Janeiro: Rocco, 2003. Tradução de Ryta Vinagre.

Moysés, Joyce. Mulheres de Sucesso Querem Poder... Amar: Como viver um amor duradouro mesmo trabalhando para atingir o topo da carreira. 2. ed. São Paulo: Gente, 2011. 
NEVES STREY, Marlene; CÚNICO, Sabrina Daiana.Teorias de Gênero: Feminismos e Transgressão. EDIPUCRS, 2017. Disponível em: <https://books.google.com.br/books?hl=es\&lr=\&id=rIwEDgAAQBAJ\&o $\mathrm{i}=\mathrm{fnd} \& \mathrm{pg}=\mathrm{PT} 6 \& \mathrm{dq}=$ Teorias $+\mathrm{de}+\mathrm{G} \% \mathrm{C} 3 \%$ AAnero ++ Feminismos $+\mathrm{e}+\mathrm{T}$ ransgress\%C3\%A3o\%0APor+Neves+Strey,Marlene,+C\%C3\%BAnico, Sabrina $+\&$ ots $=$ BI9jj3EmE6\&sig=5JIgPDKsNPsGixfmctA6qhhRtGU\&red ir_esc=y\#v=onepage \&q\&f=false > Acesso em: 13 outubro 2018

OLIVEIRA, Mainara Gomes Salesde ; TERESI, Verônica Maria. Convenção da mulher: incorporação no Brasil e influência da sociedade civil. Leopoldianum, v. 43, n. 121, p. 20, 2017. Disponível em:<http://periodicos.unisantos.br/leopoldianum/article/viewFile/761/642> Acesso em: 30 outubro 2018

ONU Mulheres. Garantir os direitos humanos das mulheres no Brasil e no mundo. Disponível em:<http://www.onumulheres.org.br/> Acesso em: 30 outubro 2018.

PERUFFO, Beatriz Maria Luchese; Santos, Rosângela Maria Herzer dos. (Org). E-bookMulheres no Poder: trajetória pessoal e profissional. Porto Alegre: OAB/RS, 2018. p. 237.Disponivel em:<http://portaldoaluno.oabrs.org.br/admin/biblioteca-digital/detalhes/id/44>Acesso em: 30 outubro 2018.

PITANGUY, Jacqueline. Carta das Mulheres Brasileiras aos Constituintes: 30 anos depois. Editora Autonomia Literária LTDA-ME, 2018. Disponível em: https://books.google.com.br/books?hl=pt-BR\&lr=\&id $=$ ZSBxDwAAQBAJ\&oi=fnd \&pg=PT70\&dq=lobby+do+baton+-+belo+sex o\&ots=oHduI5KFyW\&sig=qk9l3op9cTvJAB8hCDwRqHBI_8E\#v=onepa ge\&q\&f=false $>$ Acesso em: 13 outubro 2018.

PIZAN, Christine. A cidade das damas. Tradução e Apresentação de Luciana Eleonora de Freitas Calado Deplagne. Florianópolis: Editora Mulheres, 2012.

PLATÃO. A República. Introdução, tradução e notas de Maria Helena da Rocha Pereira, 9. ed., Lisboa, Fundação Calouste Gulbenkian, 2001. Disponível em: <https://marcosfabionuva.files.wordpress.com/2011/08/a-repc3bablica-platc3a3o-fcg-5c2aa-ed-1987.pdf>. Acesso em: 15 outubro 2018.

RATO, Helena et al. A igualdade de gênero na administração pública central portuguesa. Lisboa: Instituto Nacional de Administração, 2007. Disponível em: <https://infoeuropa.eurocid.pt/files/database/000043001-00044000/000043484.pdf>. Acesso em: 13 junho 2018. 
RATO, Helena. Valorização social do uso do tempo na promoção da igualdade de gênero. Lisboa: Instituto Nacional de Administração, 2008. Disponível em:<http://repap.ina.pt/bitstream/10782/521/3/ Valorizacao $\% 20$ social $\% 20$ do $\% 20$ uso $\% 20$ do $\% 20$ tempo $\% 20$ na $\% 20$ promocao\%20da\%20igualdade.pdf>. Acesso em: 13 setembro 2018.

REVISTA TIME. Disponível em:<http://time.com/collection/firsts/>. Acessoem:17outubro 2018.

Rocha, Maria Elizabeth Guimarães Teixeira. Os direitos da mulher nos 30 anos da constituição federal brasileira. Revista Justiça e cidadania. Rio de Janeiro, 2018, Ed 218. P. 24 - 27. Disponível em:<https://www. editorajc.com.br/wp-content/uploads/2018/10/RJC_218.pdf >Acesso em: 27 outubro 2018.

SANDBERG, Sheryl. Faça acontecer: mulheres, trabalho e a vontade de liderar. Editora Companhia das Letras, 2013.

SCHATZ, Kate; FARIAS, Jules de. Mulheres Incríveis: artistas e atletas, piratas e punks, militantes e outras revolucionarias que moldaram a história do mundo. Bauru, Sp: Alto Astral, 2017. Traduzido por : Regiane Winarski.

SEN. Amartya. Desigualdade reexaminada. 2. ed. Rio de Janeiro: Record, 2008.

SILVA, Elizabete Rodrigues. Ser mulher: uma construção social. Revista n. 01, jan., 2006, p. 33.

SILVA, Salete Maria da. o legado jus-político do lobby do batom vinte anos depois: a participação das mulheres na elaboração da Constituição Federal. Publicado em, 2008. Disponível em: <http://www. urca.br/ered2008/CDAnais/pdf/SD3_files/Salete_Maria_SILVA_2.pdf>. Acesso em: 13 junho 2018.

SIMÕES, Solange; MATOS, Solange. Ideias modernas e comportamentos tradicionais: a persistência das desigualdades de gênero no Brasil. In: SOUZA, Márcio Ferreira de (Org.). Desigualdades de gênero no Brasil: novas ideias e práticas antigas. Belo Horizonte: FinoTraço, 2012. p. 305, Cap. 1.

Site Projuris. 0 espaço delas: conheça o Women in Law Mentoring Brazil. Disponível em: <https://www.projuris.com.br/o-espaco-delas-conheca-o-women-in-law-mentoring-brazil//>. Acesso em:17outubro 2018.

SIMÕES, Solange; MATOS, Solange. Ideias modernas e comportamentos 
tradicionais: a persistência das desigualdades de gênero no Brasil. Desigualdades de gênero no Brasil: novas ideias e práticas antigas. Belo Horizonte: Argumentum, p. 15-40, 2010.

Zenger, J. \&Folkman, J. . A study in leadership: Women do it better than men. [White paper].Disponível em: < https://www.businessinsider.com/ study-women-are-better-leaders-2014-1> Acesso em: 13 outubro 2018.

WAJCMAN, Judy. Managing like a man: women and men in corporate management. Pennsylvania: The PennsylvaniaStateUniversity, 1998.

WIECKO, Ela. Ela Wiecko vai coordenar plano de ação para equidade de gênero no âmbito da ESMPU. Escola Superior do Ministério Público da União, 2018. Disponível em: <http://escola.mpu.mp.br/a-escola/ comunicacao/noticias/ela-wiecko-vai-coordenar-plano-de-acao-para-equidade-de-genero-no-ambito-da-esmpu>. Acesso em: 13 junho 2018. WIECKO, Ela. Plano de Ação para Transversalizar a Perspectiva de Gênero e Étnico-racial na Escola Superior do Ministério Público da União, ESMPU. 2018. Disponível em: <http://escola.mpu.mp.br/a-escola/comunicacao/noticias/conheca-o-plano-para-incorporar-a-perspectiva-de-genero-e-etnico-racial-na-escola/PLANO_DE_ACAO_FINAL_em_12.07.2018_11.pdf>. Acesso em: 30 outubro 2018.

WLMBR. Disponível em: <www.facebook.com/womeninlawmentoring>. Acesso em: 20 maio 2018.

I Seminário Sintrajufe/RS de Mulheres trata de empoderamento e resistência. Disponível em: <https://www.sintrajufe.org.br/ultimas-noticias-detalhe/15963/i-seminario-sintrajufe-rs-de-mulheres-trata-de-empoderamento-e-resistencia>. Acesso em:17 outubro 2018.

ZENGER, J.FOLKMAN, J. A study in leadership: Women do it better than men. [White paper], 2012. 